Review

\title{
Overview of Degrees of Freedom in the Design of PM Synchronous Machines ${ }^{\dagger}$
}

\author{
Yacine Amara ${ }^{1, *}$, Sami Hlioui ${ }^{2}$ and Mohamed Gabsi ${ }^{3}$ \\ 1 GREAH, Université Le Havre Normandie, 76600 Le Havre, France \\ 2 SATIE, Conservatoire National des Arts et Métiers, 75003 Paris, France; sami.hlioui@cnam.fr \\ 3 SATIE, Ecole Normale Supérieure Paris-Saclay, 91190 Gif-sur-Yvette, France; \\ mohamed.gabsi@ens-paris-saclay.fr \\ * Correspondence: yacine.amara@univ-lehavre.fr \\ + This paper is an extended version of our paper published in ISEF 2019-19th International Symposium \\ on Electromagnetic Fields in Machatronics, Electrical and Electronic Engineering, 29-31 August 2019, \\ Nancy, France.
}

Abstract: This contribution discusses the degrees of freedom that could be advantageously exploited in the conception of permanent magnet (PM) machines in the context of very demanding applications, such as electrical vehicle traction. The aim is to inventory degrees of freedom identified in scientific and technical literatures. Identifying these additional degrees of freedom will help positively respond to highly constrained design problems, which are appearing due to the higher usage of electrical energy in many industrial and consumer products. The goal is also to stimulate new ideas in the design of PM synchronous machines.

check for updates

Citation: Amara, Y.; Hlioui, S.; Gabsi, M. Overview of Degrees of Freedom in the Design of PM Synchronous Machines ${ }^{\dagger}$. Energies 2021, 14, 3990. https://doi.org/10.3390/en14133990

Academic Editors: Krzysztof Komęza, Paolo Di Barba and Jean-

Philippe Lecointe

Received: 13 May 2021

Accepted: 24 June 2021

Published: 2 July 2021

Publisher's Note: MDPI stays neutral with regard to jurisdictional claims in published maps and institutional affiliations.

Copyright: (c) 2021 by the authors. Licensee MDPI, Basel, Switzerland. This article is an open access article distributed under the terms and conditions of the Creative Commons Attribution (CC BY) license (https:// creativecommons.org/licenses/by/ $4.0 /)$.
Keywords: permanent magnet; electrical traction; hybrid excitation; design; conception; degrees of freedom

\section{Introduction}

Due to their attractive features, permanent magnet (PM) synchronous machines are being designed and used in several demanding applications, such as electrical traction (Toyota Prius [1], AGV Alstom [2]) (Figure 1) or renewable energy power conversion [3-6] (Figure 2).

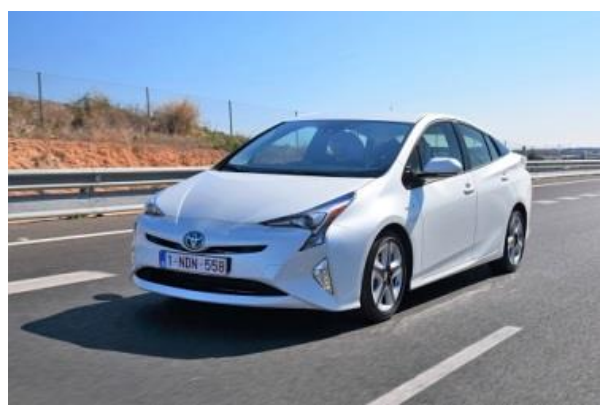

(a)

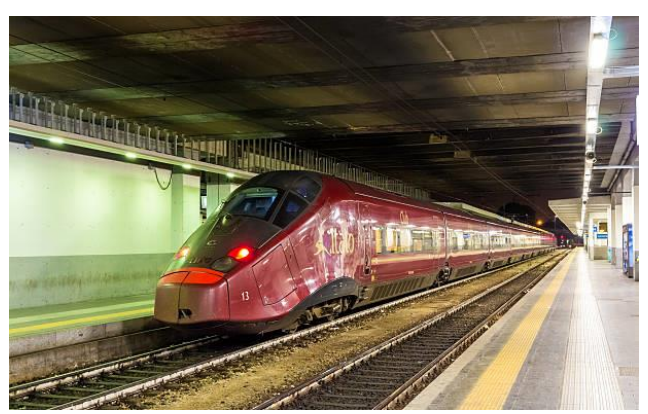

(b)
Figure 1. PM synchronous machines (PMSM) used in traction applications: (a) Toyota Prius vehicle [1]; (b) Alstom AGV train [2].

In this contribution, techniques helping to improve the performance of PM synchronous machines, from a conceptual point of view, are reviewed. These techniques help increase the number of degrees of freedom in the design of PM synchronous machines (PMSM). These additional degrees of freedom allow PMSM to easily respond to demanding applications. 


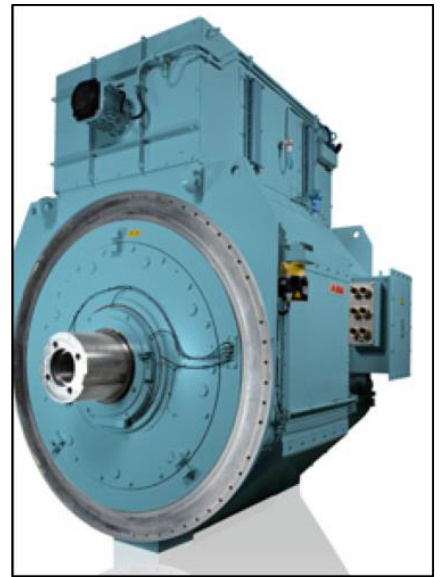

(a)

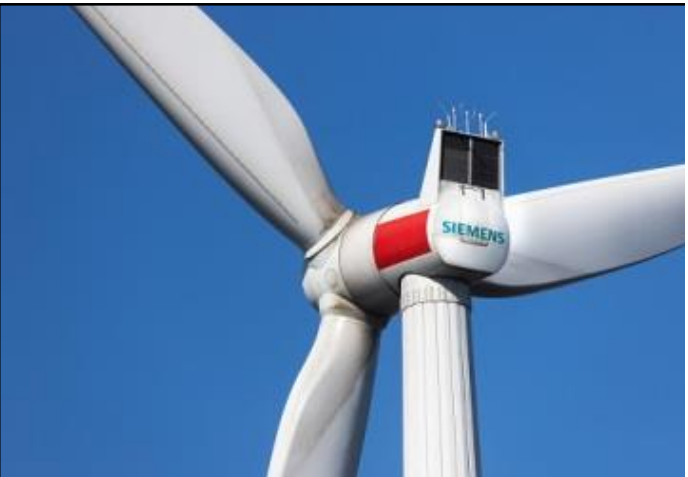

(b)

Figure 2. Wind turbine PM generators: (a) ABB 7 MW semi-integrated MS PMG for offshore wind turbines (image used with permission from ABB) [3]; (b) Siemens wind turbine [4].

Figure 3 shows the general approach used in engineering when conceiving or designing an object $[7,8]$. It is an iterative process, especially when the specifications are not clearly established. The degrees of freedom, quoted in this contribution, should be understood as the techniques that can be advantageously exploited in order to improve the conception of an object, which corresponds to the outer loop in the design model presented in Figure 3b.

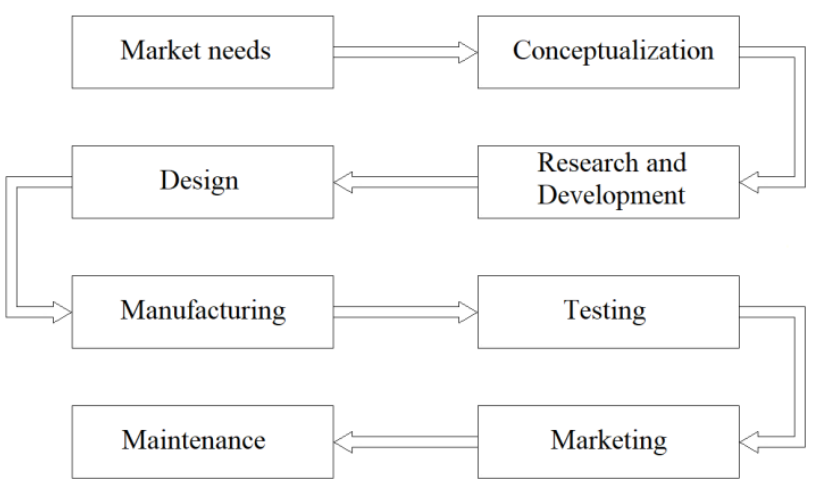

(a)

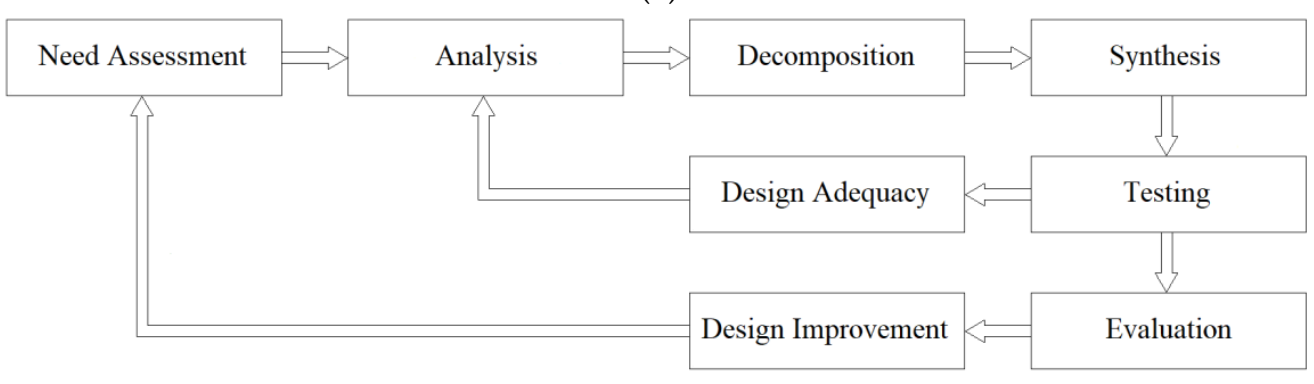

(b)

Figure 3. Comprehensive model of the design process [7]: (a) product development cycle; (b) design process.

The shift of our societies towards more sustainable uses of energy is an example of this process. Eco-design is also an illustration of this iterative process over a very long time scale. Indeed, fossil energies when first discovered were largely exploited, regardless 
of their drawbacks, which has become more visible nowadays. This fact has pushed our societies to try to find more sustainable or at least less harmful alternatives.

Main new techniques proposed in recent scientific and technical literatures [9-82] are overviewed and discussed. Some are well established and have been studied for decades, while others may be more confidential [78,79]. Even if hybrid excited machines have been studied for more than two decades, their use in industrial applications is limited [21,22].

Along with interesting overviews proposed in the scientific literature [83-86], this contribution proposes to look at the design of permanent magnet synchronous machines from a conceptual point of view, where the quoted degrees of freedom are concepts and techniques that may be used in the conceptualization of new structures (Figure 3a).

Although main concepts discussed in this contribution have been mainly developed for radial field rotating synchronous machines (Figure 4a), rotating (Figure 4a,b) and linear (Figure 4c,d) synchronous machines can be both concerned with these concepts and techniques.

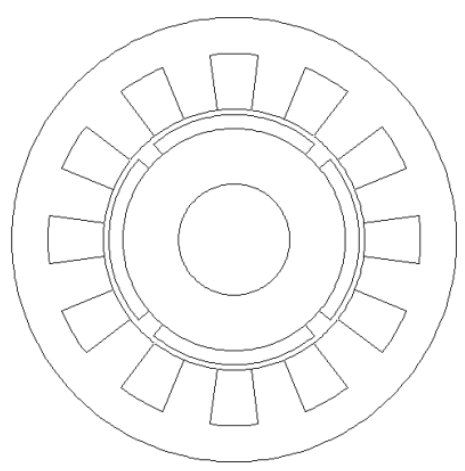

(a)

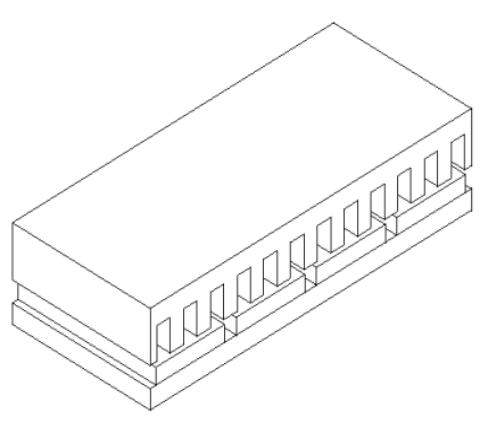

(c)

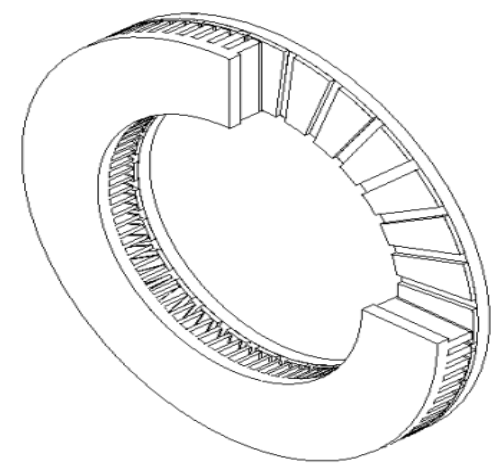

(b)

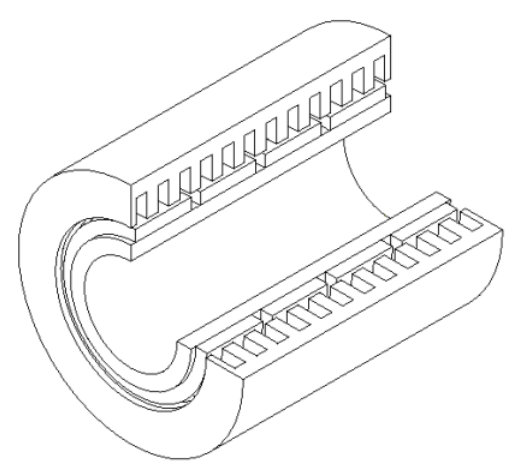

(d)

Figure 4. PM synchronous machine topologies: (a) radial field rotating machine; (b) axial field rotating machine; (c) flat linear machine; (d) tubular linear machine.

In the next section, Section 2, additional degrees of freedom are identified. Then, design techniques allowing the integration of these degrees of freedom in PMSM structures are discussed in Section 3. Different concepts are introduced and discussed. In Section 4, some original designs of PM synchronous machines are proposed. Finally, the conclusions are presented in Section 5.

\section{Degrees of Freedom Identification}

Equation (1) gives general components of electromagnetic torque in PMSM. Torque expression will help to identify the different degrees of freedom that could be integrated in the optimal design of PMSM.

$$
T=T_{P M}+T_{\text {Reluc. }}+T_{\text {Cogging }}
$$


In most applications, the cogging torque is a source of torque ripple, which designers are trying to reduce or dismiss [87]. Torque components that may be used to improve machine performances and introduce additional degrees of freedom are the two other components: PM torque $\left(T_{P M}\right)$, and reluctance torque $\left(T_{\text {Reluc. }}\right)$.

Figure 5 shows the general vector diagram of the main electrical quantities of PMSM. This diagram will be used in order to express the two useful torque components and explicate the design parameters that could be used in order to improve the PMSM performance.

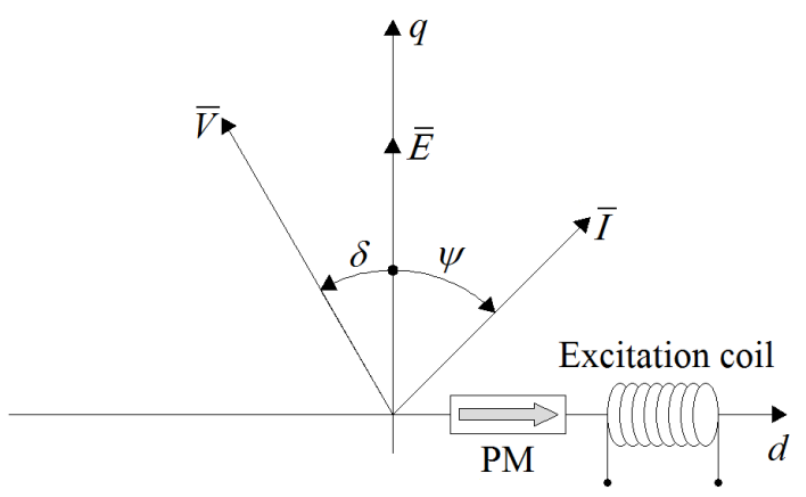

Figure 5. Vector diagram of main electrical quantities of PMSM.

\subsection{PM Torque Component}

The PM torque can be expressed as follows:

$$
T_{P M}=p \cdot \Phi_{e x c} \cdot I \cdot \cos (\psi)
$$

In this equation, two parameters can have an effect on the structural design of PMSM: $p$ (number of pole pairs), and $\Phi_{e x c}$ (excitation flux). Structures with additional degrees of freedom where these two parameters are exploited will be presented and discussed in next section. The two other parameters, $I$ and $\psi$, are control parameters. The amplitude of armature current $I$ is limited by thermal constraints or by PM demagnetization constraints.

\subsection{Reluctance Torque Component}

The reluctance torque, in classical PM synchronous machines, can be expressed as follows:

$$
T_{\text {Reluc. }}=p \cdot L_{d} \cdot(\rho-1) \cdot I^{2} \cdot \frac{\sin (2 \cdot \psi)}{2}
$$

In this equation, four parameters can have an effect on the structural design of PMSM: $p$ (number of pole pairs), $L_{d}$ ( $d$ axis inductance), $\rho$ (saliency ratio), and an additional parameter $\beta$ that can be added (4). Structures with additional degrees of freedom where these parameters are exploited will be presented and discussed in next section.

$$
T_{\text {Reluc. }}=p \cdot L_{d} \cdot(\rho-1) \cdot I^{2} \cdot \frac{\sin (2 \cdot(\psi-\beta))}{2}
$$

$\beta$ is an angle reflecting the reluctance axis shifting regarding classical $d$ axis (excitation flux axis).

In order to explain this additional degree of freedom, the superposition theorem is used. If magnetic saturation is neglected, the PM synchronous machines, where the air-gap reluctance is variable, can be seen as composed of two machines:

(1) A non-salient PM machine;

(2) A synchronous reluctance machine.

The two machines share the same shaft and are supplied with the same armature currents. Two Park's referential frames can then be defined (Figure 6): 
(1) One for the non-salient PM machine $\left(d_{P M}, q_{P M}\right)$;

(2) One for the synchronous reluctance machine $\left(d_{\text {Reluc. }}, q_{\text {Reluc. }}\right)$.

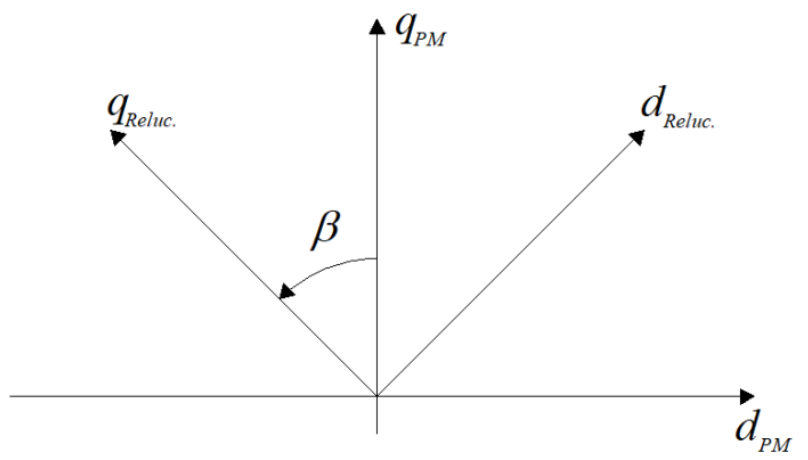

Figure 6. Park's referential frames for the two machines (non-salient PM machine and the synchronous reluctance machine).

$\beta$ is defined as the angle between the two referential frames (Figure 6). The non-salient $\mathrm{PM}$ machine referential is aligned with the global one (Figure 5).

It can then be shown that the reluctance torque component is given by Equation (4). The saliency ratio given in Equation (4) is defined as

$$
\rho=\frac{L_{q}}{L_{d}}
$$

Techniques allowing the shift in the inductance axis with respect to the PM maximum flux axis are presented in following section.

\section{Structures with Additional Degrees of Freedom}

In this section, a review of PMSM structures where the additional degrees of freedom are exploited will be presented. The aim is to explore how these techniques can be combined in order to cope with highly constrained design problems such as electrical traction, where both high torque and high speed operations are required, or aeronautical applications where the needs are expected to reach power densities as high as $20 \mathrm{~kW} / \mathrm{Kg}$ [9], or renewable energy conversion where high torque density generators are needed [10].

\subsection{Pole Changing PM Machines}

In these structures, the number of pole pairs can be varied [11,12]. The number of pole pairs can be changed between two values. This can be done whether by using low coercive field PM (Alnico PM) [11] (Figure 7) or hybrid excited rotors [12] (Figure 8). In these structures the excitation flux can also be varied.

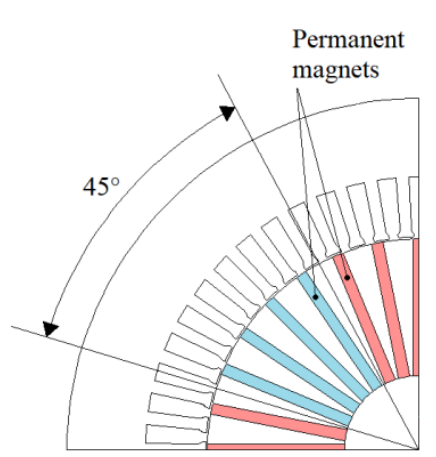

(a)

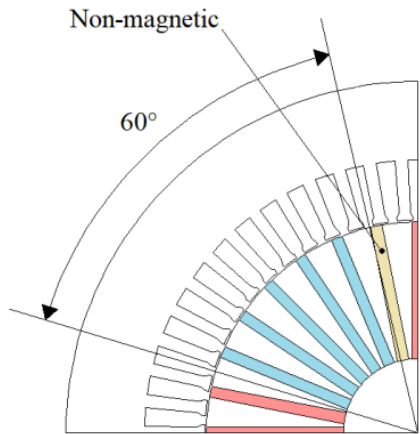

(b)

Figure 7. Illustration of memory machines principal [11]: (a) 8 pole rotor; (b) 6 pole rotor. 


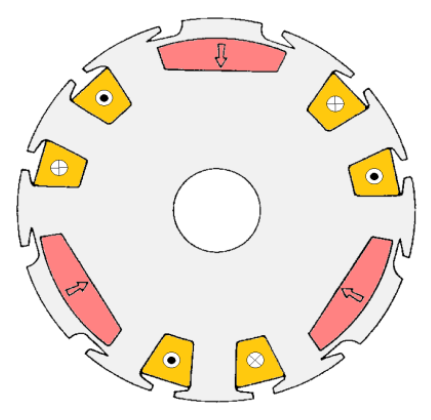

(a)

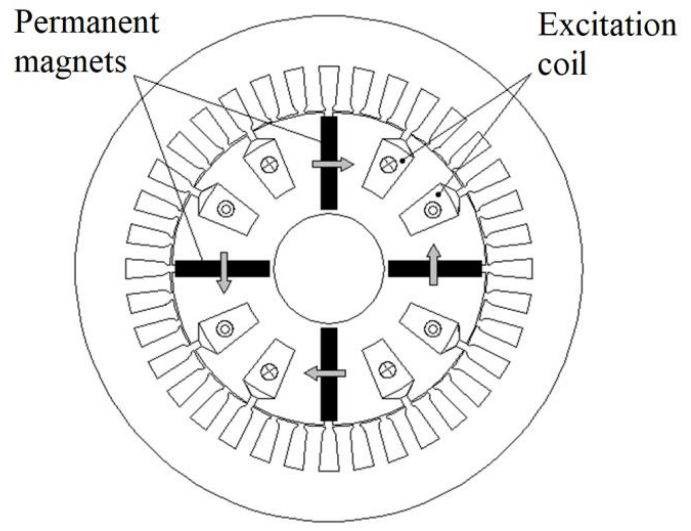

(b)

Figure 8. Hybrid excited machines with number of poles varying ability [12]: (a) 6/12 pole rotor; (b) $4 / 12$ pole rotor.

Machines where low coercive PM are used, as a means of varying the number of poles or for controlling the excitation flux, were first proposed in [11]. The author proposed to call them "memory machines". Figure 7, taken from [11], illustrates the principal of memory machines where the number of poles is changed. The low coercive PM magnetization can be continually varied by applying a short pulse of stator current.

The machine shown in Figure 7 was designed to replace induction machines used in applications requiring discrete speed control [11]. This discrete speed control is realized by changing the number of pole pairs. The pole pairs number change is obtained by reconnecting the armature phase windings accordingly, and a current pulse is used whether to demagnetize certain magnets or to inverse the polarity of some others, to switch from an eight pole (Figure 7a) to a six pole configuration (Figure 7b), or to reverse the process and come back to the initial number of poles. To do so, a small amount of stator current is required thanks to the use of low coercive force PM.

Figure 8 shows similar machines where the changes are realized thanks to excitation coils [12]. However, some differences with the previous solution do exist. While for the first configuration (Figure 7) the poles number change is discrete, the structures shown in Figure 8 allow through the excitation current control to insure a continuous control of the air-gap magnetic flux. These machines (Figure 8) can be qualified as hybrid excited machines, which are discussed in the following section.

The second difference lies in the application. The structure shown in Figure 7 is intended to be used in applications requiring discrete speed control, while the structures shown in Figure 8 are used as car alternators, which is a continuous variable speed application.

\subsection{Hybrid Excited Synchronous Machines}

In these structures, the excitation flux is created by the contribution of two sources: PM and excitation coils [13,14]. These structures have attractive features and are therefore studied by many research groups. They can be exploited to reduce the use of expensive PM, where rare earth materials are used. Due to their advantageous characteristics, this type of machine has been identified as one of the emerging technologies of modern energy conversion systems [15-17]. They have been the subject of many review papers [13,14,18].

Figure 8 shows two hybrid excited rotors. These structures combine, to a certain extent, advantages of wound field excited machines and PM machines. The presence of excitation coils allows the control of excitation flux and therefore eases high speed operations.

In addition to the flux control ability allowed by the use of these machines, another important degree of freedom is offered through the adjustment of the share of the two excitation sources [13], i.e., PM excitation and the wound field excitation. This share is defined 
using the so-called hybridization ratio $\alpha$ [13]. This parameter is defined as the ratio between the PM flux linkage $\Phi_{P M}$ and the maximum total excitation flux linkage $\Phi_{\text {exc max }}(6)$.

$$
\alpha=\frac{\Phi_{P M}}{\Phi_{\text {exc max }}}
$$

The appropriate design of the hybridization ratio (proportions of PM and excitation coils) helps improve the energy efficiency. Figure 9 illustrates how it is possible to shift the higher efficiency zone toward the most frequently solicited operating area.

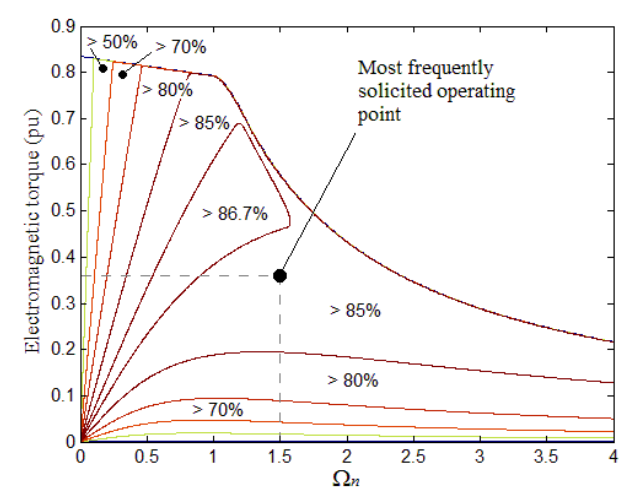

(a)

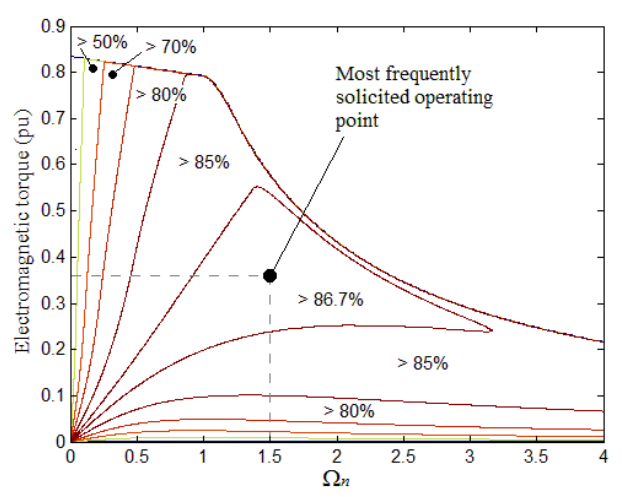

(b)

Figure 9. Efficiency maps in the "torque/speed" plane: (a) $\alpha=1 ;(\mathbf{b}) \alpha=0.72$.

The efficiency map computation is based on the hybrid excited synchronous machines model presented in Figure $10[13,19]$. Both Joule loss, in the armature and excitation windings, and iron loss are considered. The mechanical loss is neglected, but it can be easily considered if required. The total losses are given by

$$
P_{\text {Loss }}=\underbrace{R_{s} \cdot\left(i_{d}^{2}+i_{q}^{2}\right)+R_{e} \cdot I_{e}^{2}}_{\text {Joule losses }}+\underbrace{\frac{\left(v_{0 d}^{2}+v_{0 q}^{2}\right)}{R_{f}}}_{\text {Iron loss }}
$$

Figure 11 shows the algorithm on which the efficiency maps computation is based $[13,19]$. Figure 12 shows three examples of hybrid excited structures [13,20]. One of the hybrid excited synchronous structures that is attracting much attention in recent years is the flux switching hybrid excited structure (FSHES) [20]. Figure 12c shows an example of FSHES. It is a $2 \mathrm{D}$ structure [20].

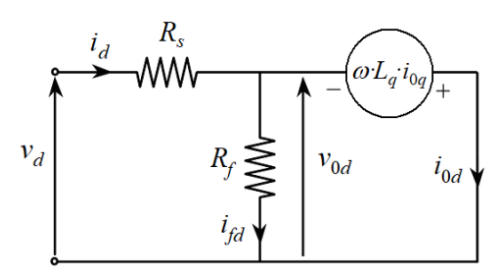

(a)

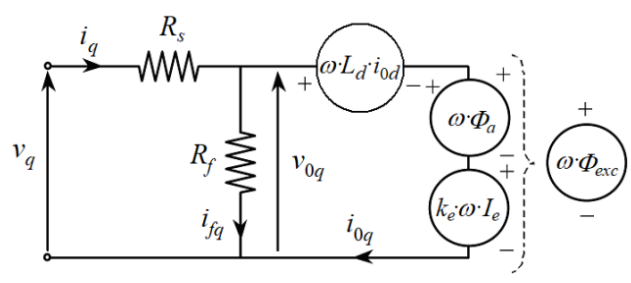

(b)

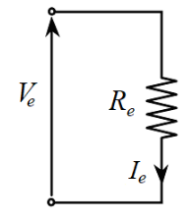

(c)

Figure 10. Hybrid excited synchronous machines model: (a) $d$ axis equivalent circuit; (b) $q$ axis equivalent circuit; (c) excitation circuit model. 


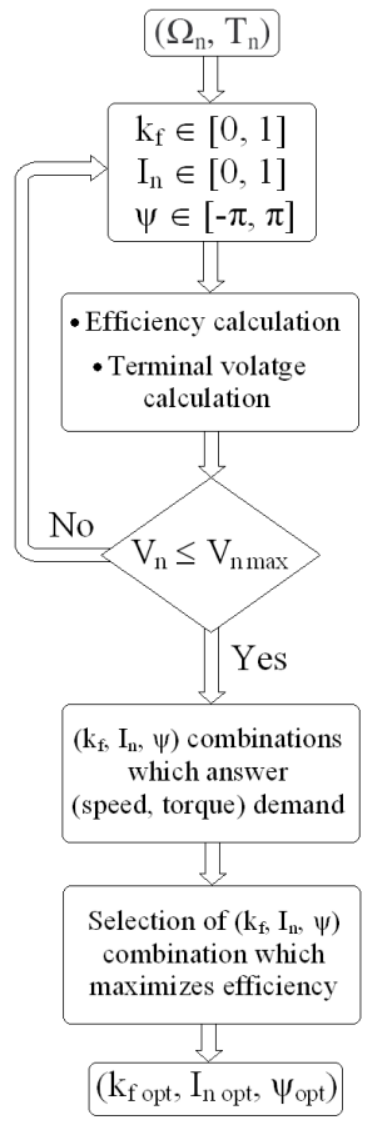

Figure 11. Algorithm for efficiency maps computation $[13,19]$.

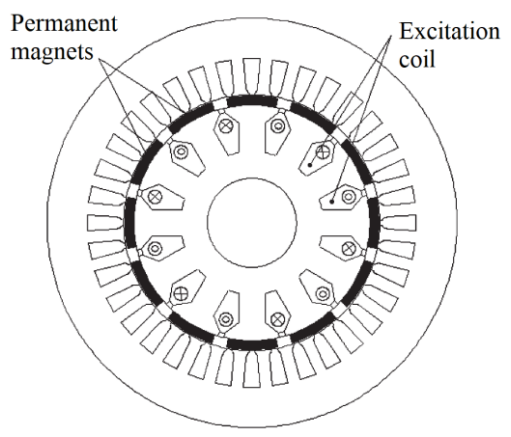

(a)

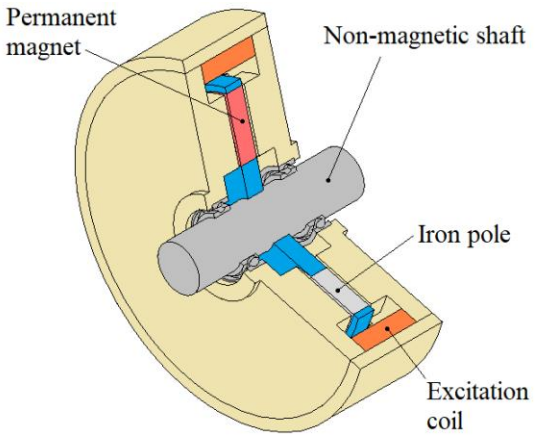

(b)

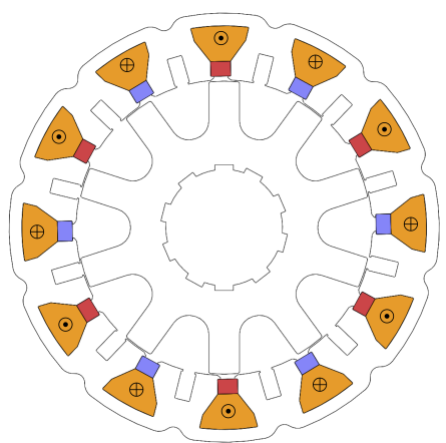

(c)

Figure 12. Examples of hybrid excited structures [13,20]: (a) hybrid excited machine (radial field 2D structure); (b) hybrid excited machine (axial field 3D structure); (c) hybrid excited flux switching machine (2D structure). 
As compared to classical PM machines, the addition of a supplemental wound field excitation circuit brings a certain complexity, which should be compensated by the benefit obtained during operation. Furthermore, the number of additional tasks that may be required for the manufacturing of these machines should not be that high. Figure 13 shows a photo of a rotor of a hybrid excited claw pole machine that is used as a starter/alternator for classical vehicles $[21,22]$. To date, this is the sole industrial application of such machines.

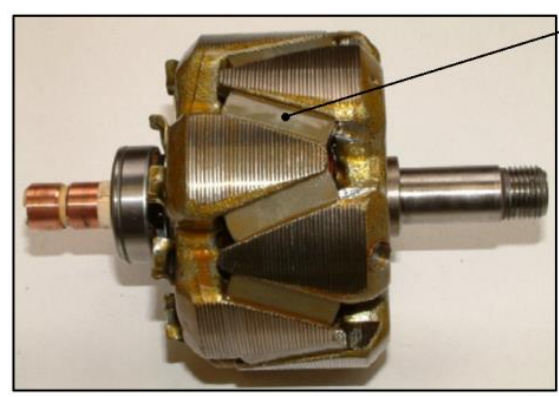

Permanent magnets

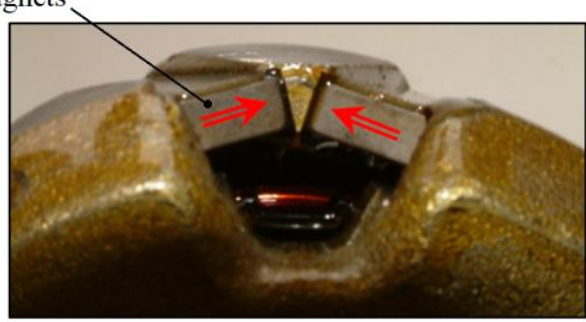

Figure 13. Hybrid excited claw pole machine used as starter/alternator [22] (image used with permission from the author).

\subsection{Variable Flux Memory Machines}

The basic idea of variable flux memory machines (VFMM) was first proposed in [23]. As hybrid excitation machines, the goal is to control the air-gap magnetic field. It is based on the use of low coercive force permanent magnets in the rotor, whose magnetization is controlled by the $d$ axis armature current. The torque is mainly produced using the $q$ axis component, avoiding therefore the risk of permanent magnet demagnetization.

The basic idea is similar to the structure shown in Figure 7, but instead of changing the polarization of the low coercive force magnets, the intensity of their magnetization is varied (controlled). The structure shown in Figure 7 is qualified as a "pole-changing memory motor" (PCMM), and the one shown in Figure 14 is qualified as a "variable flux memory motor" (VFMM).

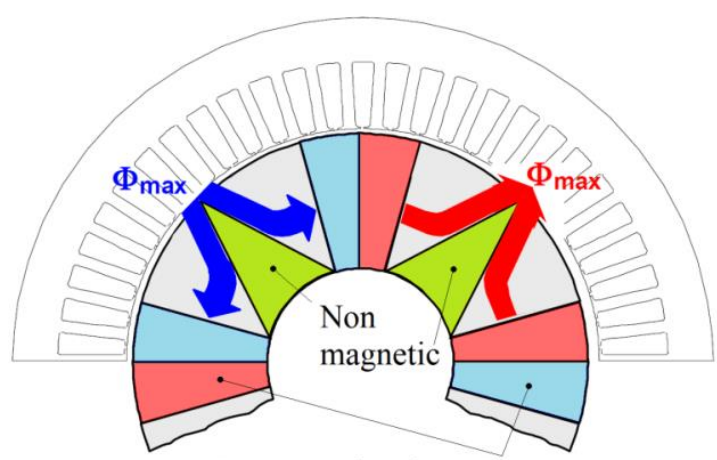

Low coercive force PM

Figure 14. Original VFMM studied in [23].

Figure 14 shows the original variable flux memory machine studied in [23]. Thanks to their trapezoidal shape, the PM parts that can be easily controlled are the parts close to the shaft. These parts offer a low reluctant path to magnetic flux as compared to these located at the rotor outer radius. The control of magnetization depends on the value of the $d$ axis armature current used for that purpose. The author in [23] compared the use of ferrite and AlNiCo magnets, and obviously the AlNiCo magnets needed much less $i_{d}$ current to control their magnetization as compared to ferrite magnets.

Many variable flux memory machines (VFMM) have been developed and studied since the concept was first proposed, and they are still researched intensively [24]. 


\subsection{Machines with Mechanically Controllable Air-Gap Flux}

The structures presented in this section suppose an external mechanical action in order to modify the air-gap magnetic flux. Interesting overviews of such structures can be found in $[25,26]$. The modification of air-gap flux is aimed at realizing a field weakening. The need for a mechanical actuation makes these structures more likely to be costly solutions as compared to more classical field weakening techniques.

The modification of air-gap magnetic flux can be done by modifying the air-gap thickness, as shown in Figure 15, for an axial field machine. Figure 16 shows a picture, taken from [27], where the field weakening is realized by modifying the machine active length (overlap length between the stator and the rotor). Figure 17 shows another example of mechanical field weakening, where one rotor portion is shifted regarding the other portion, under the same stator, in order to reduce total air-gap magnetic flux [28,29]. Figure 18 shows other examples of field weakening realized by short-circuiting the PM magnetic field [30,31]. Authors in the different contributions related to the mechanical field weakening are proposing more or less original ideas for the actuation systems. The controlling forces may be generated by mixing electromagnetic and mechanical designs parameters.

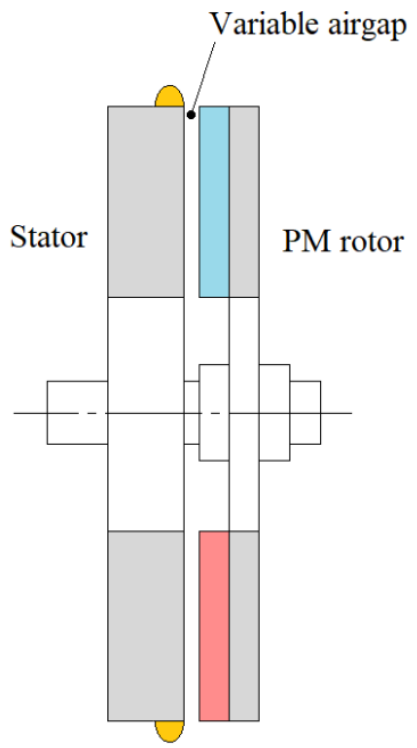

Airgap $3>$ Airgap $2>$ Airgap 1

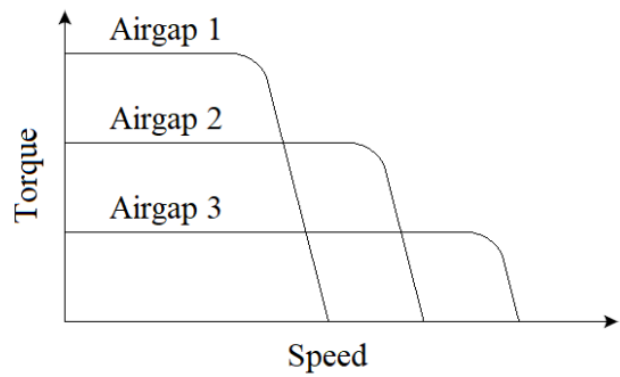

Figure 15. Axial field machine with variable air-gap [25].

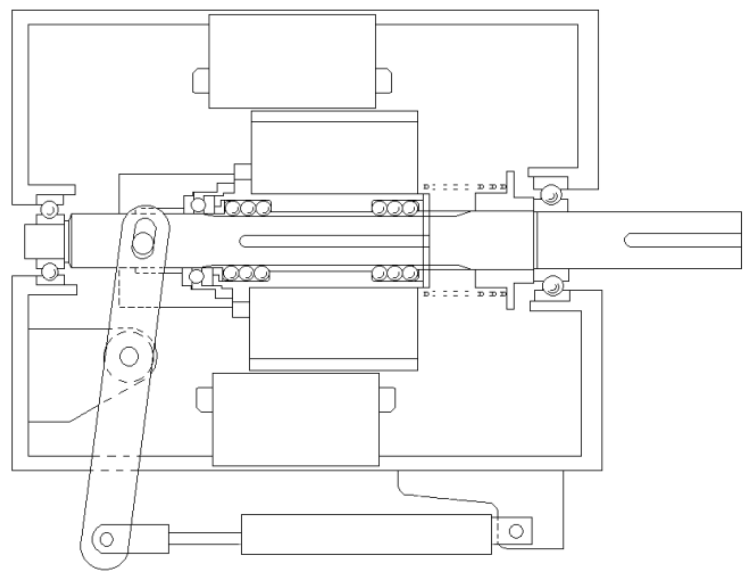

Figure 16. Brushless PM machine with variable axial rotor/stator alignment to increase speed capability [27]. 


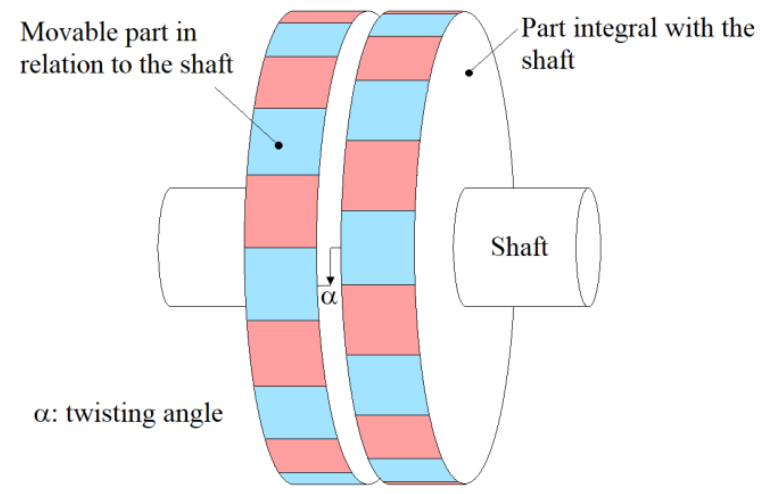

Figure 17. Mechanical field weakening using two rotor's portions [28,29].

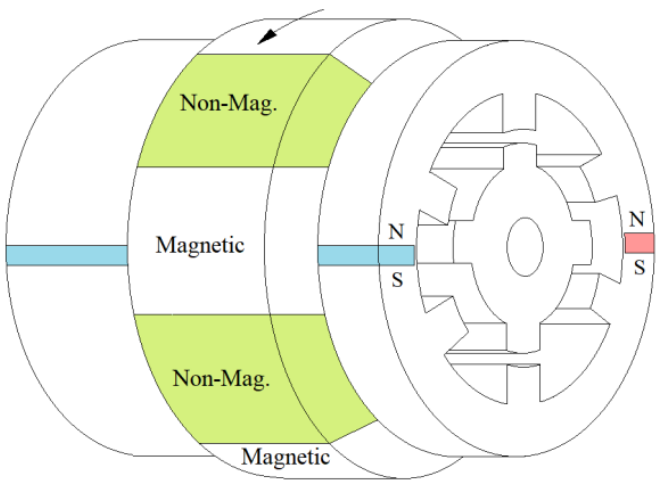

(a)

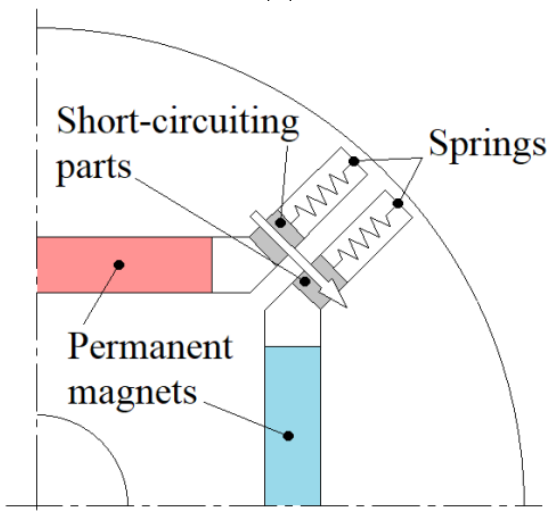

(b)

Figure 18. Field weakening via PM magnetic field short-circuiting [30,31]: (a) [30]; (b) [31].

The need for complex systems in order to shift certain parts is likely to stop the development of such systems. This type of structures is not attracting as much attention as the previous solutions for the control of air-gap magnetic field. In addition to the additional design effort that has to be provided, as compared to the other solutions, the presence of additional devices is increasing the risk of faults.

\subsection{Inductance Axis Shifted Machines}

These structures have been recently introduced and studied [32-36]. Figure 19 shows examples of such structures. Angle $\beta$, defined in Section 2.2, is advantageously exploited in order to increase the total torque. Figure 20 illustrates how the additional degrees of freedom related to the angle $\beta$ is exploited. In the case of a machine with a $T_{\text {Reluc.Max }}=T_{P M \text { Max }} / 2$, as long as the inductance axis shifting does not induce a change in 
this proportion, the total torque may be increased by nearly $16 \%$ by setting $\beta=-45$ elec. deg. The interesting features of this technique can be used to reduce the required PM volume if the total maximum torque is kept constant. In [34], the authors designed a machine based on the Toyota Prius specifications where this technique has been used. Their design seemed superior to the existing one.

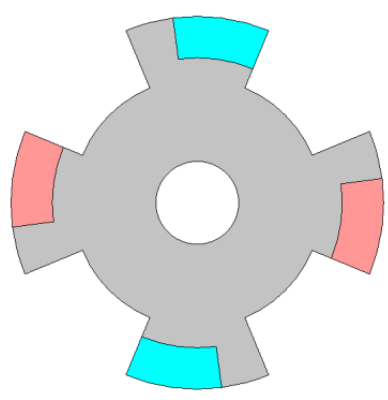

(a)

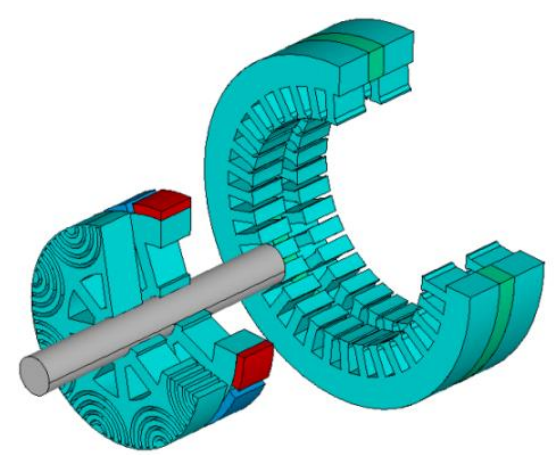

(b)

Figure 19. Inductance axis shifted structures: (a) 2D structure [32]; (b) 3D structure [34].

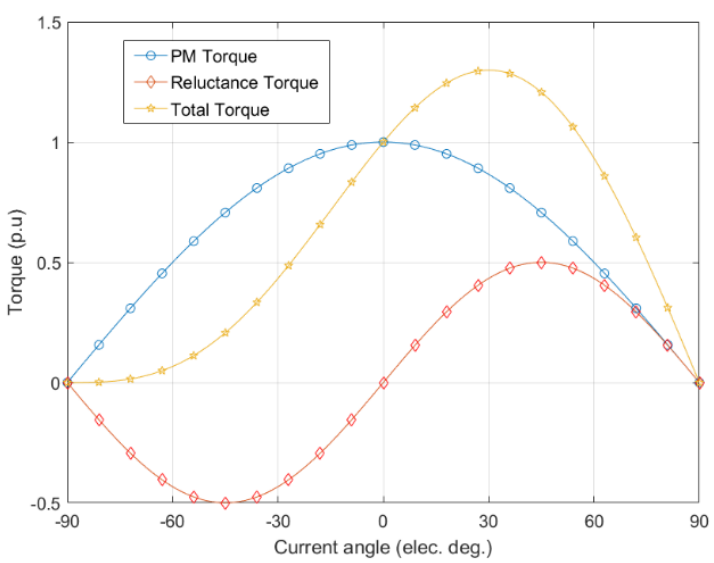

(a)

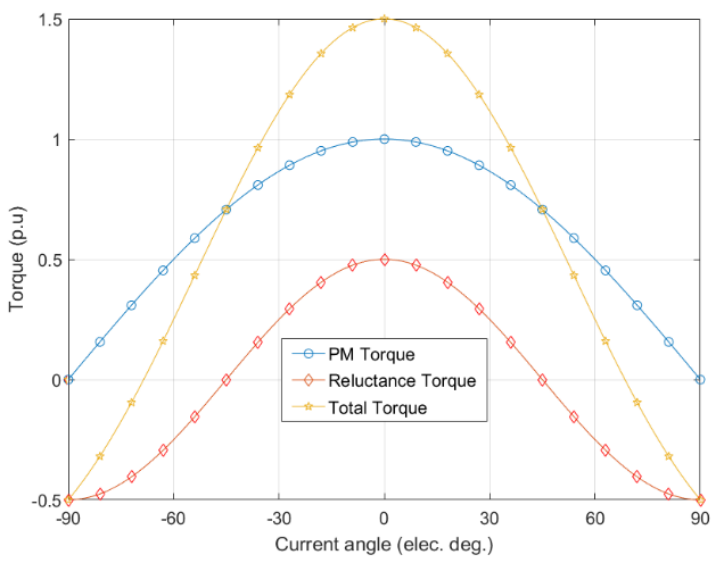

(b)

Figure 20. Torque components in classical PM machines (a), and inductance axis shifted structures (b). (a) Classical PM machines ( $\beta=0$ elec. deg.); (b) PM machine with an inductance axis shifting ( $\beta=-45$ elec. deg.). 
Figure 21a shows a rotor of a structure, patented by an industrial company [35], where the addition of slits inside the V shaped PM rotor helped increase the total torque. More recently the authors of [36] have proposed an alternative structure (Figure 21b), where the slits are placed outside the $\mathrm{V}$ shaped magnets. It seems that they have further increased the torque.

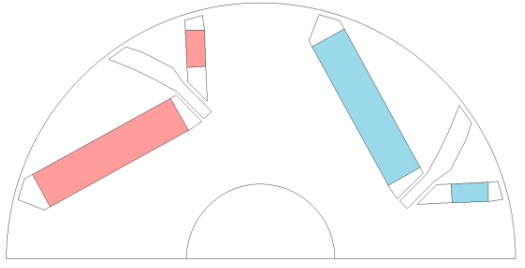

(a)

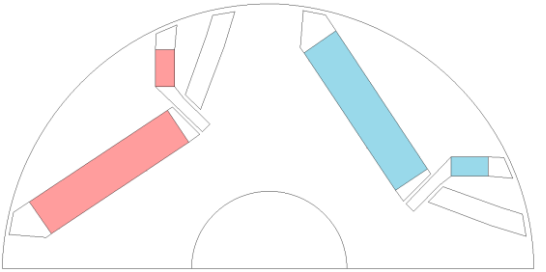

(b)

Figure 21. Inductance axis shifted structures: (a) [35]; (b) [36].

Structures shown in Figures 19a and 21 are 2D structures, while the structure shown in Figure $19 \mathrm{~b}$ can be qualified as a 3D structure, since it combines two different rotors, distributed in the axial direction. In general, 2D structures are easier to manufacture compared to the 3D ones. Machines overviewed in [36] have mainly a 2D structure.

\subsection{Machines with Magnetic Gearing Effect}

Figure 22 shows an example of a machine with a gearing effect obtained thanks to the Vernier effect [37-39]. This type of machine is used in low speed, high torque applications. This machine has a single mechanical port $[40,41]$.

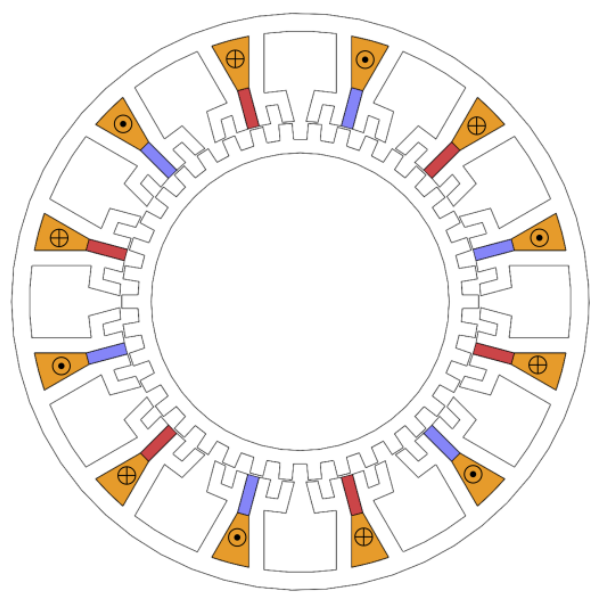

Figure 22. PM flux switching structure with Vernier effect [37].

Figure 23 shows other structures with gearing effects, which are in fact composed of PM synchronous machines associated with a magnetic gear (pseudo direct drives (PDDs)) [42]. These machines have two mechanical ports [40,41].

While the coupling between the electrical machine and the magnetic gear is done in the axial direction, for the structure shown in Figure 23a, they are both integrated in the same plane as for the structure shown in Figure 23b,c.

Structures with a gearing effect are also qualified as "flux modulation structures" [43]. These structures may be designed for transportation applications [40,44], as well as for low speed energy conversion (renewable energy conversion) [41,45]. 


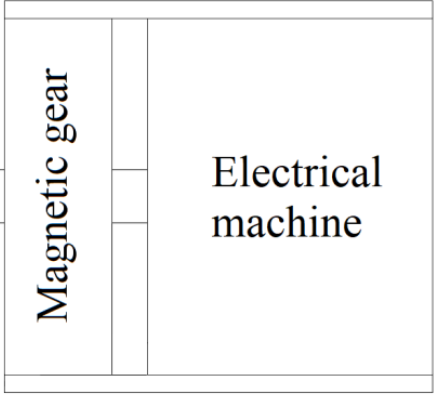

(a)

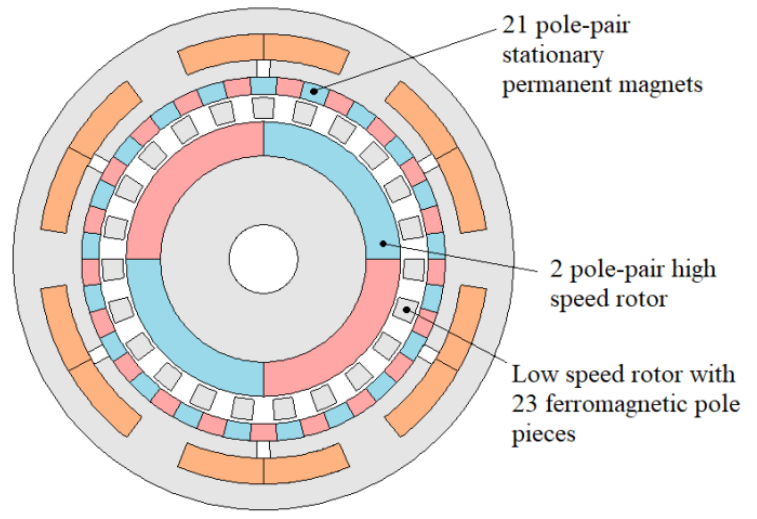

(b)

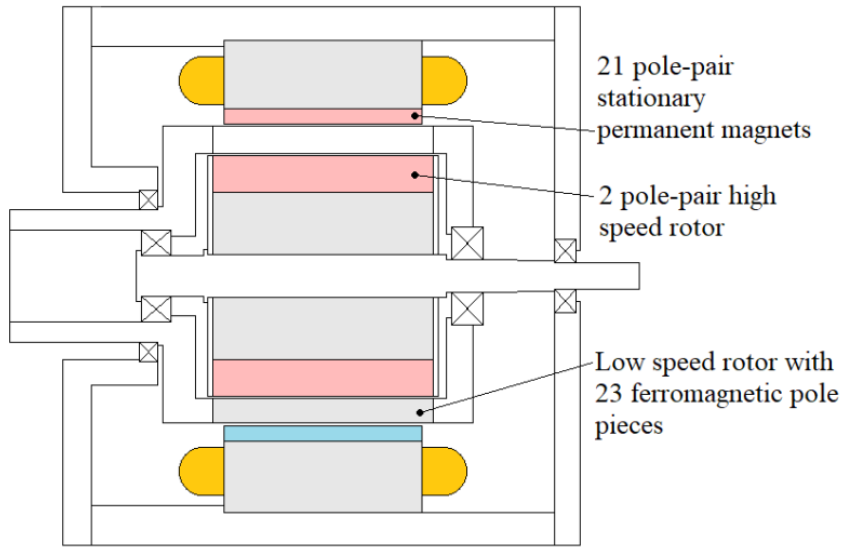

(c)

Figure 23. Pseudo direct drive examples [42]. (a) Electrical machine and magnetic gear coupled mechanically; (b) Cross sectional view of an integrated pseudo direct drive; (b) Axial cut view of the integrated pseudo direct drive.

It should be noticed that even if all the structures shown till now are rotating structures, all presented techniques are applicable to linear structures. As an example, Figure 24 shows a linear magnetic gear [46].

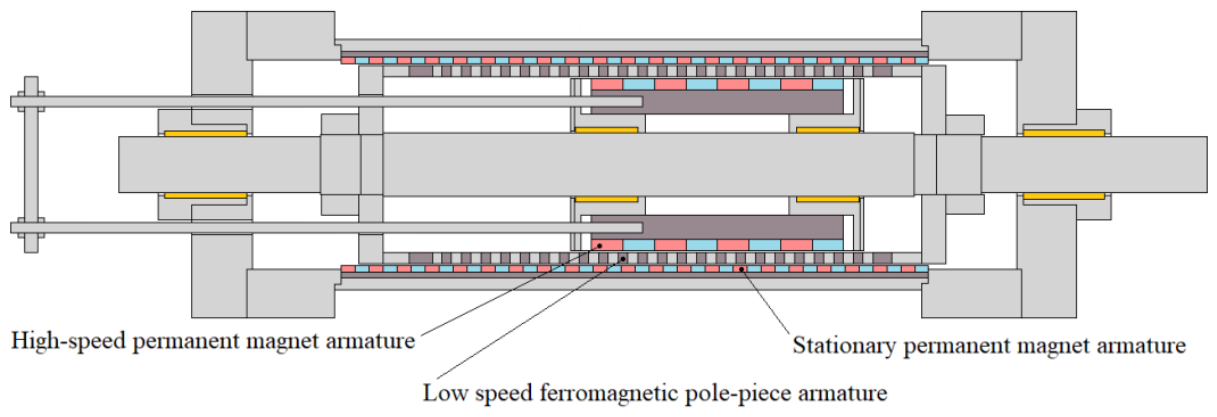

Figure 24. Linear magnetic gear [46].

Vernier machines suffer, in general, from a low power factor that implies the need for high power rated converters in order to supply them. Moreover, the magnetic gears use a huge amount of PM volume, which implies costly devices. Furthermore, in order to have high performance magnetic gears, rare earth-based PM are used, which also poses the problem of availability [47]. This is why an important research effort is being conducted to find alternatives to rare earths components for high energy PM [47]. 


\subsection{Passive Rotor PM Machines}

Having a passive rotor, or moving armature in the case of linear machines, helps to ease the cooling of electrical machines. Indeed, having passive moving parts means that all magnetic field sources, which are responsible for most of the losses, are located in the stator and are therefore easier to cool. It is much easier and efficient to cool stationary parts than moving ones.

Efficient cooling allows for improvement in the electrical machine's performances by pushing up the permissible electric loading compared to natural cooled machines. It also helps insure stable performance over time by limiting the temperature rise.

Another interesting feature of passive rotor machines is the possibility of operating at high speed without requiring a special rotor design. An interesting overview of passive rotor machines, or stator PM machines, is proposed in [48].

Figures $12 \mathrm{c}$ and 22 show examples of such machines. They both are flux switching structures.

However, having all magnetic field sources grouped into one armature limits the volume of ferromagnetic material, and as a consequence the magnetic saturation effect becomes very important. The overload capability is then limited [49].

In order to solve this problem, some authors proposed partitioning the armature holding the magnetic field sources, often the stator, into two parts, which helps increase the volume allocable to ferromagnetic material, and reduce the magnetic saturation impact on the performance.

Figure 25 shows three examples from the scientific literature. Figure 25a shows a radial field rotating machine [50], while Figure 25b,c show examples of linear machines [51,52].

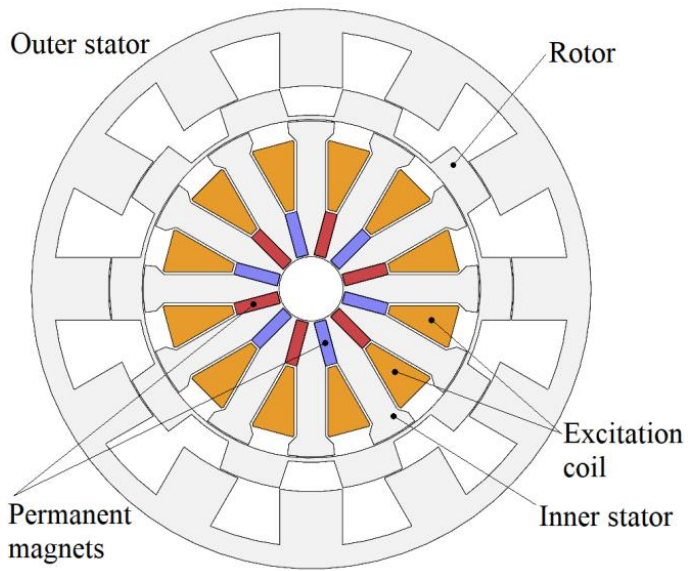

(a)

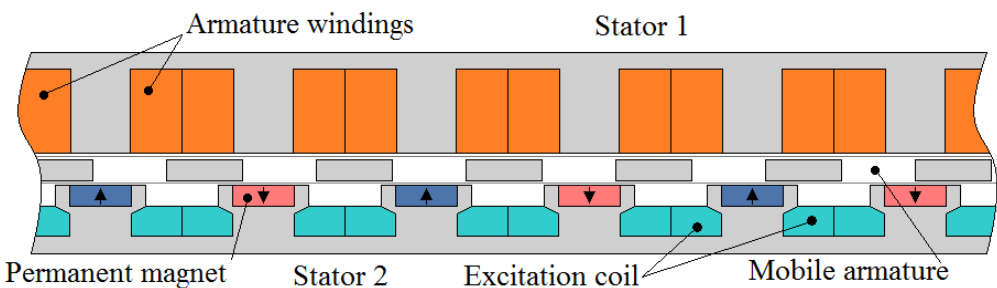

(b)

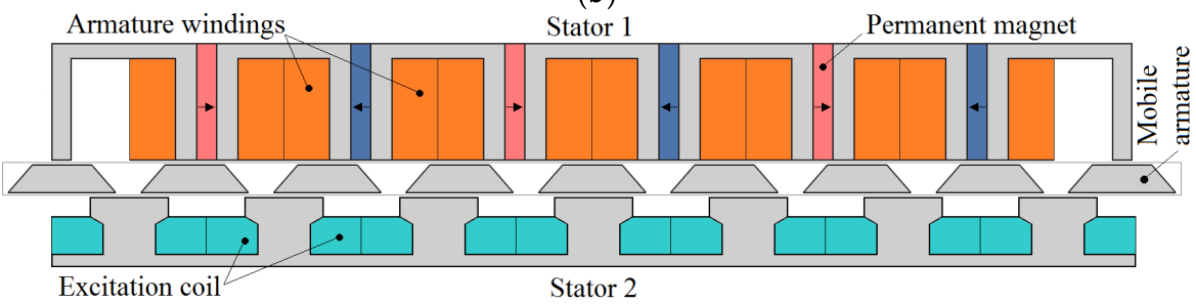

(c)

Figure 25. Partitioned stators flux switching hybrid excited machines: (a) [50]; (b) [51]; (c) [52]. 
Nevertheless, doing so will complicate the cooling (two separated armatures have to be cooled), increase the volume of these structures, and complicate their manufacturability. Mechanical stiffness of such structures may also be a concern.

\subsection{Line-Starting PM Machines}

Adding a line-starting capability to PM machines helps broaden their application scope. Indeed, with the new regulations imposing the use of more efficient machines, researchers and engineers are looking to replace the induction machines, whenever possible, by the more efficient PM machines.

Figure 26 shows an example of a line-start PM machine (LSPM) [53]. The line-start capability is obtained by accommodating a squirrel-cage in the PM rotor. Interesting studies on line-starting PM machines can be found in [53-58]. These machines are still studied [59-63], in particular for replacing induction machines, which have lower efficiency.

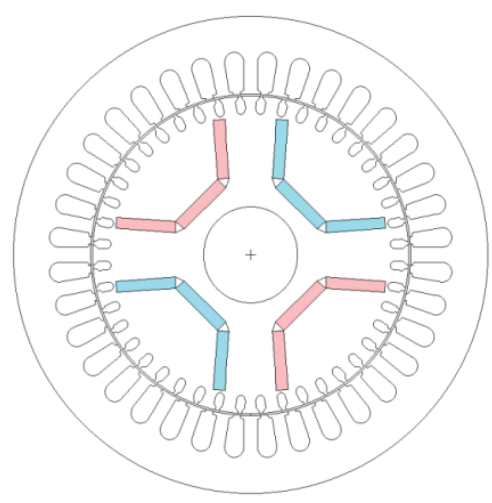

Figure 26. Line-start PM machine [53].

In [59], the authors confirmed that there exists a competing relationship between power factor $(\mathrm{PF})$ and inertia of the rotor. It is therefore necessary to find a compromise. In [60], the authors used a solid rotor along with a squirrel cage in order to improve the asynchronous starting torque. In [61], the authors used a magnetic equivalent circuit model in order to classify the line-start permanent-magnet motors according to their ability to synchronize. They performed a parametric study based on the mechanical and electromagnetic characteristics parameters of different LSPM machines. In [62], the authors confirmed the improvement of efficiency when using an LSPM machine as compared to a comparable induction machine. As in a previous contribution [62], authors of [63] obtained better performance when using a LSPM machine as compared to a comparable induction machine. The initial design they adopted was based on a commercial induction motor [63].

The main problem with these machines is the presence of squirrel cages that are subject to induced currents responsible for additional joule losses. Indeed, even if operating at the synchronous speed, the air-gap magnetic field contains harmonics that will induce currents in the squirrel cages.

\subsection{Improved Use of the Available Space}

Electrical machines exist in different topologies, such as radial field or axial field rotating machines, or plane or tubular linear machines (Figure 4).

Axial field rotating machines allow theoretically a better space usage as compared to radial field machines and have therefore higher torque density [64].

Some authors have proposed to combine the radial field and axial field topologies in order to improve the torque density [65-68].

Figure 27a,b show two structures studied in [67,68], respectively. While in [67], the authors used a special armature windings configuration allowing for the covering of both the axial and radial surfaces, in [68], two separated stators with their respective armature windings were used for the axial field part and the radial field part, respectively. In both 
contributions, the authors reported improvement of the power density of these structures as compared to classical ones.

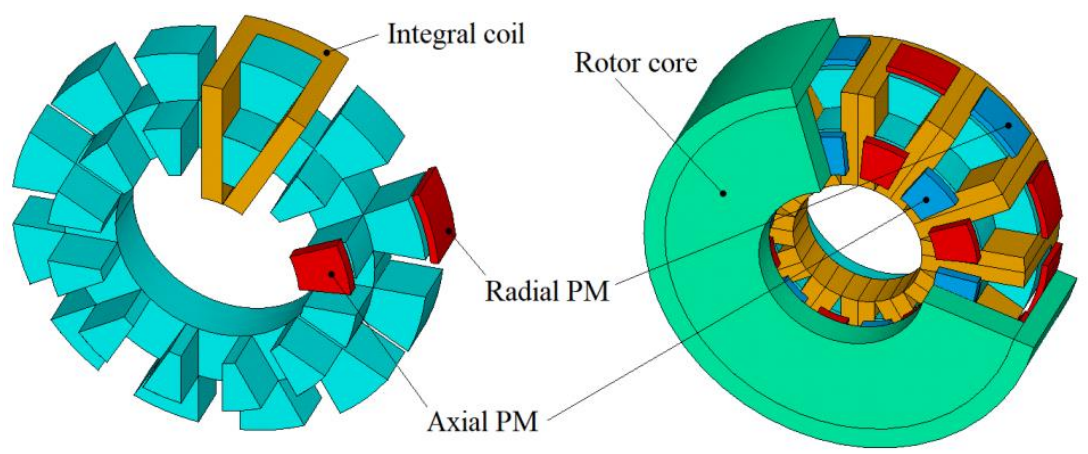

(a)

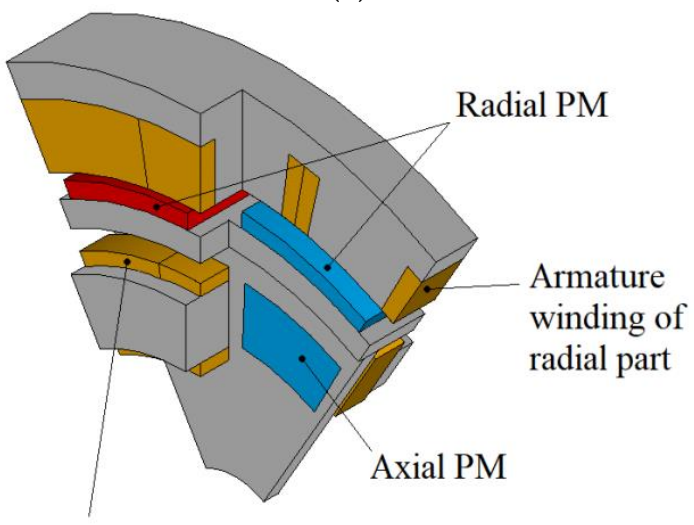

Armature winding of axial part

(b)

Figure 27. Hybrid flux permanent magnet machines: (a) [67]; (b) [68].

The idea behind the better usage of available space is to increase the air-gap area within a given available volume. The force production is proportional to the air-gap area. The multi-air-gaps principal was formalized in $[69,70]$, and has been used in order to increase the force (or torque) density in electrical machines by many researchers [71,72]. Figure 28 shows an example of a linear machine where this principle has been used to reach higher force densities [71].

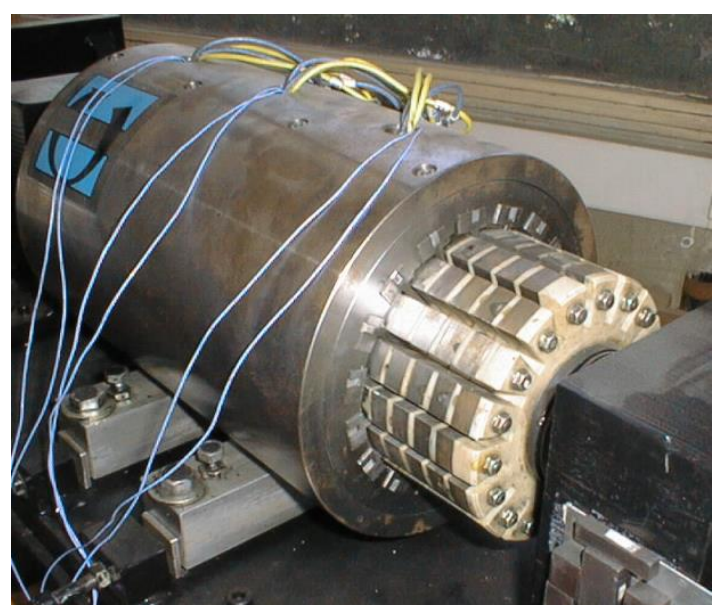

Figure 28. Multi-air-gap linear machine [71] (image used with permission from the authors). 
The availability of isotropic magnetic materials with good mechanical and electromagnetic characteristics is limiting the development of these machines. In the structure studied in [67], the authors used SMCs (soft magnetic composites) and laminated materials. Mechanical stiffness is also an issue for these machines [73].

\subsection{Mechanical Modularity and Integration}

Integration is a way to increase the power density of engineering devices. The main idea is to integrate different functions, realized by separated devices or parts, much closer whenever it is possible. For electrical drives, different integration aspects are discussed in the scientific literature [74-82].

Integration is often discussed for electrical drives to bring closer the power electronics converters and the electrical machines [74,75]. An interesting overview of this type of integration is presented in [74]. This is due to the fact that for the main large consumer products, the power levels and corresponding torque (or force) density are not too high, which does not require one to also explore mechanical integration.

Nevertheless, with the shift of our societies toward better usage of energy, new applications are emerging, such as wind turbine generators or electrical airplanes, where high power density and/or torque (or force) density electrical machines are required. Mechanical integration then becomes an important issue.

For the wind turbine market, the actual tendency is to develop offshore wind farms. Wind turbines are installed offshore, and for an installed power, it is better to have few units with high power, instead of many lower power units [81]. This is due to accessibility of the offshore regions where the wind turbines farms are installed, which limits the maintenance possibilities. It is then better to reduce the number of units in order to reduce the maintenance needs.

This results in high power density and high torque density electrical generators, where mechanical modularity and integration should be given particular attention.

The mechanical modularity is important, because it helps reduce the maintenance costs. It is much easier to carry small, low weight parts.

Mechanical integration is also important, because in electrical machines designed for applications requiring high power density and high torque density, the so-called "nonactive" parts mass can exceed the active parts mass $[9,80]$. It is then pertinent to integrate different parts insuring different functions together [77].

Figure 29 shows a concept that was proposed for a $10 \mathrm{MW}$ wind turbine, where an integration of the electrical generator's rotor with the wind turbine blades has been conceptualized [82].

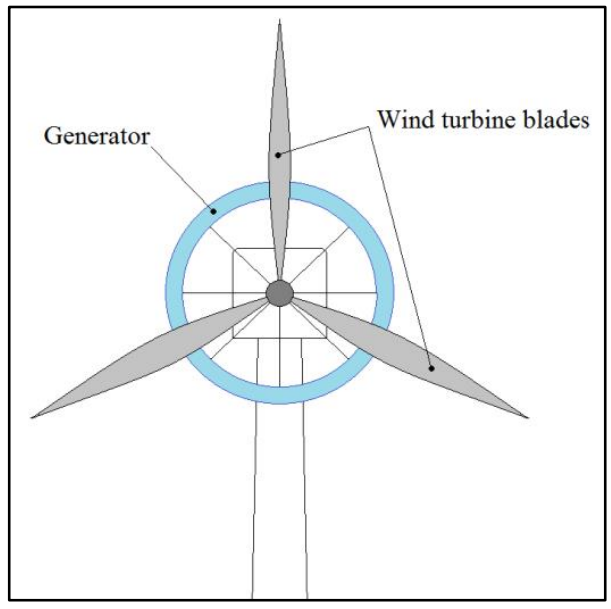

Figure 29. Conceptual view of an integrated wind turbine generator [82]. 
In [77], the authors proposed to integrate the bearing, or guidance, function with the electrical generator rotor. They proposed a buoyant rotor structure.

Mechanical integration is also discussed in the scientific and technical literature for smaller machines $[78,79]$. In $[78,79]$, the authors proposed integrating the bearing function in the air-gap of linear tubular machines. The authors in [79] performed this integration for a surface mounted tubular linear machine. They reported a mitigated impact on the performance.

This section highlights the importance of having a multidisciplinary approach when designing electrical machines. The mechanical aspects should be given particular attention.

\section{Idea Stimulation}

Figures 30-32 propose structures where some of the previously described techniques are combined. Figure 30 presents a parallel hybrid excited PM machine with a shifted inductance axis rotor, and in Figure 31 is presented a series hybrid excited synchronous machine with line-starting capability. Figure 32 shows a conceptual view of a linear tubular flux switching machine, where the bearing function is integrated in the machine air-gap [88].

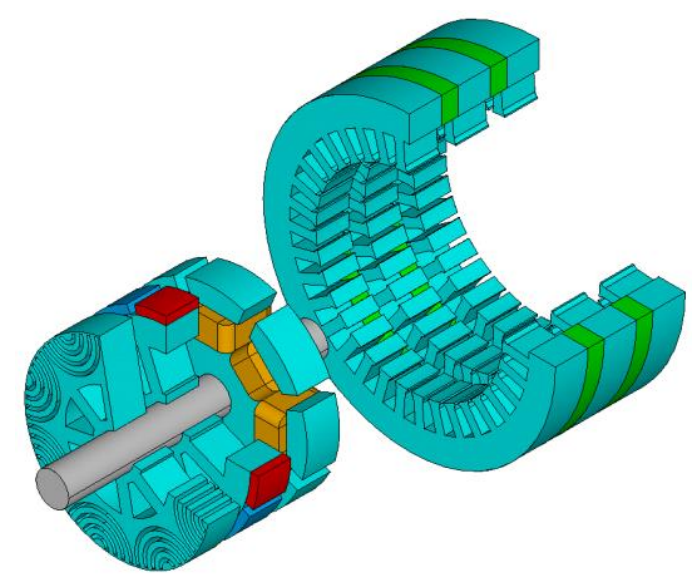

Figure 30. Hybrid excited PM machine with a shifted inductance axis rotor.

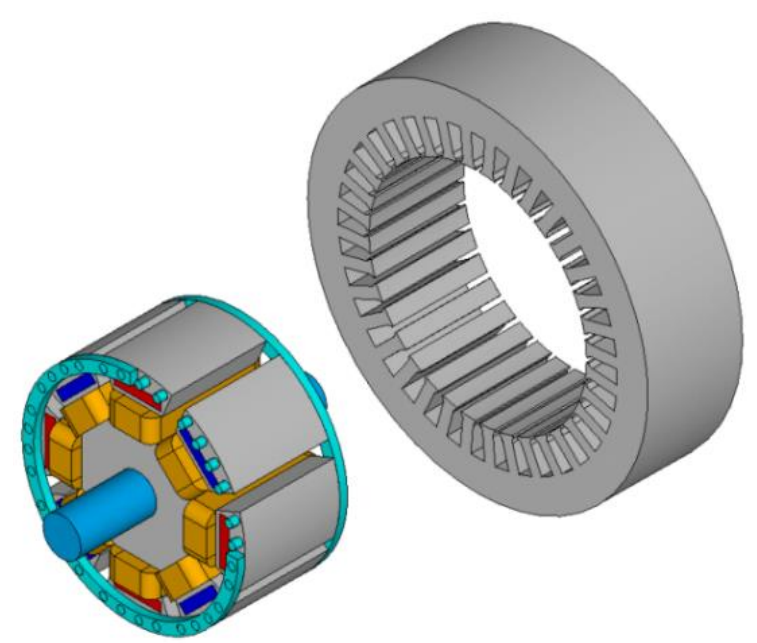

Figure 31. Hybrid excited PM machine with line-start capability. 


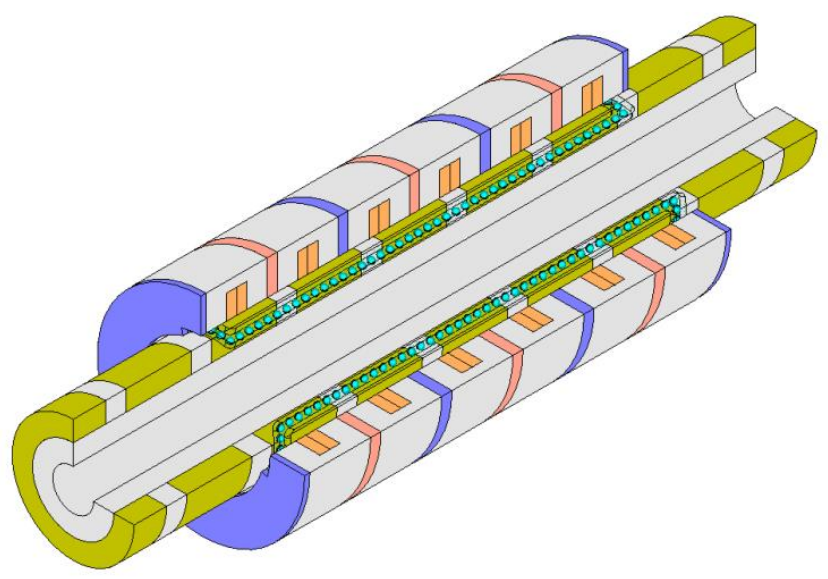

Figure 32. Conceptual 3D cut view of a TLFSPM structure with bearings integrated in the mechanical air-gap [88].

Along with the reviewed techniques related to the design of permanent magnet synchronous machines, important improvements in the performance of electrical machines can be sought from the development of high-performance materials [89]. SMCs (soft magnetic composites), if their electromagnetic and mechanical characteristics are improved [89-91], may be advantageously used, and new manufacturing techniques such as additive manufacturing [92-94] may also bring some added value to electrical machines, in particular the 3D structures, mainly for the reduction of manufacturing costs.

It is obvious that combining these different techniques will complicate the design and construction process of such structures as compared to more classical PM machines. Nevertheless, this drawback should be put into perspective with the much more complex IC engines. Indeed, considering the number of pieces required for the construction of even the simplest IC engine, the construction of even the most complex electric machine requires much less operations and simpler production lines.

The concepts presented in this section have not been realized yet, but there is nothing preventing these solutions from being fully operational. A prototype based on the concept of Figure 32 will be designed. The practical feasibility will be the subject of a future contribution.

\section{Conclusions}

An overview of degrees of freedom that may be advantageously exploited in the design of PM machines has been presented in this contribution. The main aim is to stimulate new ideas and technique combinations for broadening applications of PM synchronous machines and/or to ease their design in highly constrained applications.

While increasing the power density can be obtained by increasing the operating speed, the increase of torque (or force) density is more challenging. The combination of the different discussed concepts, along with the use of appropriate materials, is mandatory to obtain a significant increase of the torque (or force) density of PM synchronous machines.

Degrees of freedom discussed in this contribution are those that could be exploited at the conceptual level. Their adoption must be analyzed in light of their suitability regarding the application specifications. They are complementary to the optimization approaches used at the components level [95-98].

The combination of these degrees of freedom results in more complex structures, but new manufacturing techniques are being developed, and it can be expected that the complexity issue can be overcome.

The overview of these degrees of freedom has highlighted the necessity of a multidisciplinary approach in the design of electrical machines. This is imposed by the electrical machines' natures, which are electromechanical devices, and the need to consider the design at both the components and systems levels. 
Presently, where new systems have to comply with different demanding constraints, engineers and researchers have to find solutions in different engineering domains, mainly electrical and mechanical engineering (Power Mechatronics) $[99,100]$ in the case of electric machines and combine their advantages.

Author Contributions: All authors have equally contributed to this manuscript. All authors have read and agreed to the published version of the manuscript.

Funding: This research received no external funding.

Institutional Review Board Statement: Not applicable.

Informed Consent Statement: Not applicable.

Data Availability Statement: The data presented in this study are available on request from the corresponding author.

Conflicts of Interest: The authors declare no conflict of interest.

\section{References}

1. Sarlioglu, B.; Morris, C.T.; Han, D.; Li, S. Driving toward accessibility: A review of technological improvements for electric machines, power electronics, and batteries for electric and hybrid vehicles. IEEE Ind. Appl. Mag. 2017, 23, 14-25. [CrossRef]

2. Marc Debruyne. L'AGV et les Trains du Future; Club EEA: Lille, France, 2009.

3. Product Note: Wind Power Generators: Medium Speed Permanent Magnet Generator (MS PMG), (C) Copyright 2012 ABB. All Rights Reserved. Available online: https://search.abb.com/library/Download.aspx?DocumentID=9AKK105541\& LanguageCode=en\&DocumentPartId=\&Action=Launch (accessed on 1 July 2021).

4. Siemens Showcases New Gearless Direct Drive Wind Generator (Germany). Available online: https:/ / www.offshorewind.biz/20 12/09/20/siemens-showcases-new-gearless-direct-drive-wind-generator-germany / (accessed on 1 July 2021).

5. Haliade 150-6MW Offshore Wind Turbine. Available online: http://pdf.archiexpo.com/pdf/alstom/haliade-150-6mw-offshorewind-turbine-wallchart/88574-260511.html (accessed on 1 July 2021).

6. The Offshore Wind Farm and Wind Power Industry. Available online: https://www.ge.com/renewableenergy/wind-energy/ offshore-wind (accessed on 1 July 2021).

7. Braha, D.; Maimon, O. The design process: Properties, paradigms, and structure. IEEE Trans. Syst. Man Cybern. Part A Syst. Hum. 1997, 27, 146-166. [CrossRef]

8. Braha, D.; Maimon, O. A Mathematical Theory of Design: Foundations, Algorithms and Applications; Applied Optimization; SpringerScience and Business Media, B.V.: Berlin/Heidelberg, Germany, 1998; Volume 17. [CrossRef]

9. Golovanov, D.; Gerada, D.; Sala, G.; Degano, M.; Trentin, A.; Connor, P.H.; Xu, Z.; La Rocca, A.; Galassini, A.; Tarisciotti, L.; et al. 4MW Class High Power Density Generator for Future Hybrid-Electric Aircraft. IEEE Trans. Transp. Electrif. 2021. [CrossRef]

10. Zhang, Z.; Matveev, A.; Øvrebø, S.; Nilssen, R.; Nysveen, A. State of the art in generator technology for offshore wind energy conversion systems. In Proceedings of the 2011 IEEE International Electric Machines and Drives Conference (IEMDC 2011), Niagara Falls, ON, Canada, 15-18 May 2011; pp. 1131-1136.

11. Ostovic, V. Pole-changing permanent-magnet machines. IEEE Trans. Ind. Appl. 2002, 38, 1493-1499. [CrossRef]

12. Akemakou, A.D.; Phounsombat, S.K. Electrical Machine with Double Excitation, Especially a Motor Vehicle Alternator. U.S. Patent 6147429, 14 November 2000.

13. Amara, Y.; Vido, L.; Gabsi, M.; Haong, E.; Ben Ahmed, A.H.; Lécrivain, M. Hybrid excitation synchronous machines: Energyefficient solution for vehicles propulsion. IEEE Trans. Veh. Technol. 2009, 58, 2137-2149. [CrossRef]

14. Hlioui, S.; Gabsi, M.; Ben Ahmed, H.; Barakat, G.; Amara, Y.; Chabour, F.; Paulides, J.J.H. Hybrid Excited Synchronous Machines. IEEE Trans. Magn. 2021. [CrossRef]

15. Capolino, G.-A.; Cavagnino, A. New trends in electrical machines technology-Part II. IEEE Trans. Ind. Electron. 2014, 61, 4931-4936. [CrossRef]

16. Liu, C.; Chau, K.T.; Kirtley, J.L.; Chan, C.C.; Rajashekara, K.; Cheng, M.; Jahns, T.M.; Zhang, Z.; Kwon, B.; Shek, J.; et al. Guest Editorial Emerging Electric Machines and Drives for Smart Energy Conversion. IEEE Trans. Energy Convers. 2018, 33, 1931-1933. [CrossRef]

17. Akatsu, K.; Sugimoto, H.; Aiso, K.; Gao, Y.; Fernandez, D.; Matsumori, H. Message from Editors. CES Trans. Electr. Mach. Syst. 2019, 3, 231-232. [CrossRef]

18. Spooner, E.; Khatab, S.A.W.; Nicolaou, N.G. Hybrid excitation of AC and DC machines. In Proceedings of the 1989 Fourth International Conference Electrical Machines and Drives Conference, London, UK, 13-15 September 1989; pp. 48-52.

19. Amara, Y.; Hlioui, S.; Ben Ahmed, H.; Gabsi, M. Pre-optimization of hybridization ratio in hybrid excitation synchronous machines using electrical circuits modelling. Math. Comput. Simul. 2021, 184, 118-136. [CrossRef]

20. Nasr, A.; Hlioui, S.; Gabsi, M.; Mairie, M.; Lalevee, D. Design optimization of a hybrid-excited flux-switching machine for aircraft-safe DC power generation using a diode bridge rectifier. IEEE Trans. Ind. Electron. 2017, 64, 9896-9904. [CrossRef] 
21. Richard, D.; Dubel, Y. Valeo stars technology: A competitive solution for hybridization. In Proceedings of the 2007 Power Conversion Conference, Nagoya, Japan, 2-5 April 2007; pp. 1601-1605.

22. Albert, L. Modélisation et Optimisation des Alternateurs à griffes. Application au Domaine Automobile. Ph.D. Thesis, Energie électrique, Institut National Polytechnique de Grenoble-INPG, Grenoble, France, 2004. (In French).

23. Ostovic, V. Memory motors-A new class of controllable flux PM machines for a true wide speed operation. In Proceedings of the Conference Record IEEE-IAS Annual Meeting, 30 September-4 October 2001; pp. 2577-2584. [CrossRef]

24. Yang, H.; Lin, H.; Zhu, Z.Q. Recent advances in variable flux memory machines for traction applications: A review. CES Trans. Electr. Mach. Syst. 2018, 2, 34-50. [CrossRef]

25. Lipo, T.A.; Aydin, M. Field weakening of permanent magnet machines-Design approaches. In Proceedings of the EPE Power Electronics and Motion Control Conference (EPE-PEMC 04), Riga, Latvia, 1-24 June 2013.

26. John, M.M. Propulsion Systems for Hybrid Vehicles, 2nd ed.; IET Renewable Energy Series 7; IET Renewable Energy, 2010.

27. Lawrence, P.Z.; Jerry, W.M. Brushless Permanent Magnet Motor with Variable Axial Rotor/Stator Alignment to Increase Speed Capability. U.S. Patent 6,492,753 B2, 10 December 2002.

28. Kraßer, B.; Rattei, F. Mechanical Field Weakening with Actuation by the Stator Currents. In Proceedings of the International Conference on Electrical Machines, Helsinki, Finland, 28-30 August 2000; Volume 4, pp. 1956-1960.

29. Rattei, F.; Kraßer, B. Efficiency of a permanent magnet polyphase machine with a mechanical field weakening. In Proceedings of the EPE'99 EPFL, Lausanne, Switzerland, 7-9 September 1999.

30. Thomas, A.L.; Liao, Y.; Liang, F. Field Weakening for a Doubly Salient Motor with Stator Permanent Magnets. U.S. Patent $5,455,473,3$ October 1995 .

31. Lei, M.; Sanada, M.; Morimoto, S.; Takeda, Y. Basic study of flux-weakening for interior permanent magnet synchronous motor with moving iron piece. IEEJ Trans. Ind. Appl. 1998, 118, 1458-1459. (In Japanese) [CrossRef]

32. Zhao, W.; Lipo, T.A.; Kwon, B.-I. Optimal design of a novel asymmetrical rotor structure to obtain torque and efficiency improvement in surface inset PM motors. IEEE Trans. Magn. 2015, 51, 8100704. [CrossRef]

33. Zhao, W.; Chen, D.; Lipo, T.A.; Kwon, B.-I. Performance improvement of ferrite-assisted synchronous reluctance machines using asymmetrical rotor configurations. IEEE Trans. Magn. 2015, 51, 8108504. [CrossRef]

34. Yang, H.; Li, Y.; Lin, H.; Zhu, Z.Q.; Lyu, S.; Wang, H.; Fang, S.; Huang, Y. Novel reluctance axis shifted machines with hybrid rotors. In Proceedings of the 2017 IEEE Energy Conversion Congress and Exposition (ECCE), Cincinnati, OH, USA, 1-5 October 2017. [CrossRef]

35. Takahashi, T.; Miyama, Y.; Nakano, M.; Yamane, K. Permanent Magnet Rotating Electric Machine. Japan PCT Patent Appl. WO 2019/064801 A1, 4 April 2019.

36. Zhu, Z.Q.; Xiao, Y. Novel Magnetic-field-shifting Techniques in Asymmetric Rotor Pole Interior PM Machines with Enhanced Torque Density. IEEE Trans. Magn. 2021.

37. Zhu, Z.Q.; Chen, J.T.; Pang, Y.; Howe, D.; Iwasaki, S.; Deodhar, R. Analysis of a novel multi-tooth flux-switching PM brushless AC machine for high torque direct-drive applications. IEEE Trans. Magn. 2008, 44, 4313-4316. [CrossRef]

38. Lee, C.H. Vernier motor and its design. IEEE Trans. Power App. Syst. 1963, 82, 343-349. [CrossRef]

39. Kim, B.; Lipo, T.A. Operation and design principles of a PM Vernier motor. IEEE Trans. Ind. Appl. 2014, 50, 3656-3663. [CrossRef]

40. Xu, L. Dual-mechanical-port electric machines-concept and application of a new electric machine to hybrid electrical vehicles. IEEE Ind. Appl. Mag. 2009, 15, 44-51. [CrossRef]

41. Sun, X.; Cheng, M.; Hua, W.; Xu, L. Optimal design of double-layer permanent magnet dual mechanical port machine for wind power application. IEEE Trans. Magn. 2009, 45, 4613-4616. [CrossRef]

42. Atallah, K.; Rens, J.; Mezani, S.; Howe, D. A novel "pseudo" direct-drive brushless permanent magnet machine. IEEE Trans. Magn. 2008, 44, 4349-4352. [CrossRef]

43. Li, D.; Qu, R.; Li, J. Topologies and analysis of flux-modulation machines. In Proceedings of the IEEE Energy Conversion Congres Exposition, Montreal, QC, Canada, 20-24 September 2015; pp. 2153-2160. [CrossRef]

44. Tong, C.; Wang, M.; Zheng, P.; Bai, J.; Liu, J. Characteristic analysis and functional validation of a brushless flux-modulated double-rotor machine for HEVs. IEEE Trans. Indus. Electron. 2019, 66, 663-673. [CrossRef]

45. Magnomatics: Wind Energy Activity. Available online: http://www.magnomatics.com/pages/applications/renewable-energy. htm (accessed on 1 July 2021).

46. Holehouse, R.C.; Atallah, K.; Wang, J. Design and realization of a linear magnetic gear. IEEE Trans. Magn. 2011, 47, 4171-4174. [CrossRef]

47. Girtan, M.; Wittenberg, A.; Grilli, M.L.; de Oliveira, D.P.S.; Giosuè, C.; Ruello, M.L. The Critical Raw Materials Issue between Scarcity, Supply Risk, and Unique Properties. Materials 2021, 14, 1826. [CrossRef]

48. Wang, Y.; Deng, Z. Hybrid Excitation Topologies and Control Strategies of Stator Permanent Magnet Machines for DC Power System. IEEE Trans. Ind. Electron. 2012, 59, 4601-4616. [CrossRef]

49. Amara, Y.; Barakat, G.; Paulides, J.J.H.; Lomonova, E. Overload capability of linear flux switching permanent magnet machines. In Proceedings of the Ninth International Symposium on Linear Drives for Industry Applications (LDIA13), Applied Mechanics and Materials, Hangzhou, China, 7-10 July 2013; Volume 416-417, pp. 345-352. [CrossRef]

50. Yang, H.; Zhu, Z.Q.; Lin, H.; Chu, W. Flux adjustable permanent magnet machines: A technology status review. Chin. J. Electr. Eng. 2016, 2, 14-30. [CrossRef] 
51. Zeng, Z.; Lu, Q. Investigation of novel partitioned-primary hybrid-excited flux-switching linear machines. IEEE Trans. Ind. Electron. 2018, 65, 9804-9813. [CrossRef]

52. Zeng, Z.; Lu, Q. A novel hybrid-excitation switched-flux linear machine with partitioned-excitations. IEEE Trans. Magn. 2019, 55, 7502204. [CrossRef]

53. Jha, A.K. Optimization of Line Start Permanent Magnet Synchronous Motor for Magnet Cost Reduction. Master's Thesis, Royal Institute of Technology, The School of Electrical Engineering, Electrical Energy Conversion, Stockholm, Sweden, 2012.

54. Miller, T.J.E. Synchronization of line-start permanent-magnet AC motors. IEEE Trans. Power Appl. Syst. 1984, 103, 1822-1828. [CrossRef]

55. Knight, A.M.; McClay, C.I. The design of high-efficiency line-Start motors. IEEE Trans. Ind. Appl. 2000, 36, 1555-1562. [CrossRef]

56. Kurihara, K.; Azizur Rahman, M. High-efficiency line-start interior permanent-magnet synchronous motors. IEEE Trans. Ind. Appl. 2004, 40, 789-796. [CrossRef]

57. Ding, T.; Takorabet, N.; Sargos, F.-M.; Wang, X. Design and analysis of different line-start PM synchronous motors for oil-pump applications. IEEE Trans. Magn. 2009, 45, 1816-1819. [CrossRef]

58. Mingardi, D.; Bianchi, N. Line-start PM-assisted synchronous motor design, optimization, and tests. IEEE Trans. Indus. Electron. 2017, 64, 9739-9747. [CrossRef]

59. Sorgdrager, A.J.; Wang, R.-J.; Grobler, A.J. Multiobjective design of a line-start PM motor using the Taguchi method. IEEE Trans. Ind. Appl. 2018, 54, 4167-4176. [CrossRef]

60. Yan, B.; Wang, X.; Yang, Y. Comparative parameters investigation ofcomposite solid rotor applied to line-start permanent-magnet synchronousmotors. IEEE Trans. Magn. 2018, 54, 8206305. [CrossRef]

61. Wymeersch, B.; De Belie, F.; Rasmussen, C.B.; Vandevelde, L. Classification Method to Define Synchronization Capability Limits of Line-Start Permanent-Magnet Motor Using Mesh-Based Magnetic Equivalent Circuit Computation Results. Energies 2018, 11, 998. [CrossRef]

62. Zöhra, B.; Akar, M.; Eker, M. Design of A Novel Line Start Synchronous Motor Rotor. Electronics 2019, 8, 25. [CrossRef]

63. Knypiński, Ł.; Pawełoszek, K.; Le Menach, Y. Optimization of Low-Power Line-Start PM Motor Using Gray Wolf Metaheuristic Algorithm. Energies 2020, 13, 1186. [CrossRef]

64. Sitapati, K.; Krishnan, R. Performance comparisons of radial and axial field, permanent-magnet, brushless machines. IEEE Trans. Ind. Appl. 2001, 37, 1219-1226. [CrossRef]

65. Jack, A.G.; Mecrow, B.C.; Maddison, C.P. Combined radial and axial permanent magnet motors using soft magnetic composites. In Proceedings of the 9th IEMDC, Seattle, WA, USA, 9-12 May 1999; pp. 25-29. [CrossRef]

66. Wei, X.; Yang, K.; Pan, Z.; Xie, H.; Zhu, C.; Zhang, Y. Design of a novel axial-radial flux permanent magnet motor. In Proceedings of the 17th ICEMS, Hangzhou, China, 24-25 October 2014; pp. 80-84. [CrossRef]

67. Seo, J.M.; Ro, J.-S.; Rhyu, S.-H.; Jung, I.-S.; Jung, H.-K. Novel hybrid radial and axial flux permanent-magnet machine using integrated windings for high-power density. IEEE Trans. Magn. 2015, 51, 8100804. [CrossRef]

68. Ishikawa, T.; Amada, S.; Segawa, K.; Kurita, N. Proposal of a radial- and axial-flux permanent-magnet synchronous generator. IEEE Trans. Magn. 2017, 53, 8105204. [CrossRef]

69. Rioux, C. Théorie générale comparative des machines électriques établie à partir des équations du champ électromagnétique. RGE 1970, 79, 415-421.

70. Rioux, C. Aspects préliminaires de la théorie des machines électriques comportant des matériaux ferromagnétiques. Rev. Phys. Appl. 1980, 15, 1505-1515. [CrossRef]

71. Ben Ahmed, H.; Prevond, L.; Multon, B. Structures polyentrefers: Solutions pour les entrainements directs? In Proceedings of the Colloque Conversion Electromécanique Directe (CEMD), Cachan, France, 4 February 1999; pp. 95-100. Available online: https:/ / hal.archives-ouvertes.fr/hal-00674080/document (accessed on 1 July 2021).

72. Vermaak, R.; Kamper, M.J. Design Aspects of a Novel Topology Air-Cored Permanent Magnet Linear Generator for Direct Drive Wave Energy Converters. IEEE Trans. Indus. Electron. 2012, 59, 2104-2115. [CrossRef]

73. Enrici, P.; Dumas, F.; Matt, D. Impact of the assembly constraints on a multi-air gap linear motor. In Proceedings of the 2012 International Conference on Electrical Machines (ICEM), Marseille, France, 2-5 September 2012; 2012. [CrossRef]

74. EL-Refaie, A.M. Integrated electrical machines and drives: An overview. In Proceedings of the 2015 IEEE International Electric Machines \& Drives Conference (IEMDC), Coeur d'Alene, ID, USA, 10-13 May 2015. [CrossRef]

75. Al Ghossini, H.; Dang, T.T.; Duchesne, S. A New Concept for Deeper Integration of Converters and Drives in Electrical Machines: Simulation and Experimental Investigations. Open Phys. 2019, 17, 809-815. [CrossRef]

76. Shrestha, G.; Polinder, H.; Bang, D.J.; Ferreira, J.A.; McDonald, A.S. A new concept for weight reduction of large direct drive machines. In Proceedings of the 2008 International Conference on Electrical Machines (ICEM), Vilamoura, Portugal, 6-9 September 2008. [CrossRef]

77. Bang, D.-J.; Polinder, H.; Ferreira, J.A.; Hong, S.-S. Structural mass minimization of large direct-drive wind generators using a buoyant rotor structure. In Proceedings of the 2010 IEEE Energy Conversion Congress and Exposition, Atlanta, GA, USA, 12-16 September 2010. [CrossRef]

78. Ausderau, D.; Hitz, M.; Rohner, R. Linear Motor. Europäisches Patentamt. EP 2390990A1, 25 May 2011. 
79. Maurus, Q.; Canders, W.-R.; Henke, M. Increasing the force per unit volume of tubular drives by raising the integration degree. In Proceedings of the 11th International Symposium on Linear Drives for Industry Applications (LDIA2017), Osaka, Japan, 6-8 September 2017; pp. 1-6.

80. McDonald, A.S.; Mueller, M.A.; Polinder, H. Structural mass in direct-drive permanent magnet electrical generators. IET Renew. Power Gener. 2008, 2, 3-15. [CrossRef]

81. Gjerde, S.S.; Undeland, T. Power conversion system for transformer-less offshore wind turbine. In Proceedings of the 2011 14th European Conference on Power Electronics and Applications, Birmingham, UK, 30 August-1 September 2011.

82. Borgen, E. Introduction of the Sway Turbine ST10. In Proceedings of the IQPC 3rd International Conference Drivetrain Concepts for Wind Turbines, Bremen, Germany, 22-24 October 2012.

83. Boldea, I.; Nasar, S.A. Linear Electric Actuators and Generators; Cambridge University Press: Cambridge, UK, 1997; ISBN 139780521480178.

84. Gieras, J.F. Permanent Magnet Motor Technology: Design and Applications; CRC Press: Boca Raton, FL, USA, 2009; ISBN 139781420064407.

85. Gieras, J.F.; Piech, Z.J.; Tomczuk, B. Linear Synchronous Motors: Transportation and Automation Systems; CRC Press: Boca Raton, FL, USA, 2017; ISBN 9781138072053.

86. Boldea, I.; Tutelea, L. Reluctance Electric Machines: Design and Control; CRC Press: Boca Raton, FL, USA, 2018; ISBN 9780367733933.

87. Jahns, T.M.; Soong, W.L. Pulsating torque minimization techniques for permanent magnet ac motor drives: A review. IEEE Trans. Indus. Electron. 1996, 43, 321-330. [CrossRef]

88. Haidar, D.; Amara, Y. Mechanical Construction and Bearing Function Integration in Tubular Linear Flux Switching Machines. In Proceedings of the International Symposium on Linear Drives for Industry Application (LDIA2021), Wuhan, China, 1-3 July 2021.

89. Fernando, N.; Hanin, F. Magnetic materials for electrical machine design and future research directions: A review. In Proceedings of the 2017 IEEE International Electric Machines and Drives Conference, Miami, FL, USA, 21-24 May 2017. [CrossRef]

90. Shokrollahi, H.; Janghorban, K. Soft magnetic composite materials (SMCs). J. Mater. Process. Tech. 2007, 189, 1-12. [CrossRef]

91. Krings, A.; Cossale, M.; Tenconi, A.; Soulard, J.; Cavagnino, A.; Boglietti, A. Magnetic materials used in electrical machines: A comparison and selection guide for early machine design. IEEE Ind. Appl. Mag. 2017, 23, 21-28. [CrossRef]

92. $\mathrm{Wu}, \mathrm{F}$; EL-Refaie, A.M. Toward additively manufactured electrical machines: Opportunities and challenges. IEEE Trans. Ind. Appl. 2020, 56, 1306-1320. [CrossRef]

93. Wu, F.; EL-Refaie, A.M.; Al-Qarni, A. Additively Manufactured Hollow Conductors Integrated with Heat Pipes: Design Tradeoffs and Hardware Demonstration. IEEE Trans. Ind. Appl. 2021. [CrossRef]

94. Ayat, S.; Simpson, N.; Dagusé, B.; Rudolph, J.; Lorenz, F.; Drury, D. Design of shaped-profile electrical machine windings for multi-material additive manufacture. In Proceedings of the 2020 International Conference on Electrical Machines (ICEM), Gothenburg, Sweden, 23-26 August 2020. [CrossRef]

95. Gamba, M.; Pellegrino, G.; Cupertino, F. Optimal number of rotor parameters for the automatic design of Synchronous Reluctance machines. In Proceedings of the 2014 International Conference on Electrical Machines (ICEM), Berlin, Germany, 2-5 September 2014. [CrossRef]

96. Chiu, M.-T.; Chiang, J.-A.; Lin, C.-H. Design and Optimization of a Novel V-Type Consequent-Pole Interior Permanent Magnet Synchronous Motor for Applying to Refrigerant Compressor. In Proceedings of the 21th ICEMS, Jeju, Korea, 7-10 October 2018; pp. 413-418. [CrossRef]

97. Di Barbaa, P.; Mognaschia, M.E.; Rezaeia, N.; Lowther, D.A.; Rahman, T. Many-objective shape optimisation of IPM motors for electric vehicle traction. Int. J. Appl. Electromagn. Mech. 2019, 60, 149-162. [CrossRef]

98. Mutluer, M. Analysis and Design Optimization of Tubular Linear Voice Coil Motor for High Thrust Force and Low Copper Loss. IEEE Can. J. Electr. Comput. Eng. 2021, 44, 165-170. [CrossRef]

99. ENESYS. Available online: http:/ / www.enesys.ruhr-uni-bochum.de/ueber_uns/index.html.en (accessed on 1 July 2021).

100. Amara, Y.; Hlioui, S. Degrees of freedom in the design of PM synchronous machines. In Proceedings of the 19th International Symposium on Electromagnetic Fields in Machatronics, Electrical and Electronic Engineering, Nancy, France, 29-31 August 2019. 